\title{
Interactive Effects of Organic Fertilizers and Drought Stress on Growth and Nutrient Content of Brassica juncea at Vegetative Stage
}

\author{
Addisie Geremew (D), Laura Carson *, Selamawit Woldesenbet, Charles Carpenter, Elisha Peace \\ and Aruna Weerasooriya
}

check for updates

Citation: Geremew, A.; Carson, L.; Woldesenbet, S.; Carpenter, C.; Peace, E.; Weerasooriya, A. Interactive Effects of Organic Fertilizers and Drought Stress on Growth and Nutrient Content of Brassica juncea at Vegetative Stage. Sustainability 2021, 13, 13948. https://doi.org/10.3390/ su132413948

Academic Editors: Othmane Merah, Purushothaman Chirakkuzhyil Abhilash, Magdi T. Abdelhamid, Hailin Zhang and Bachar Zebib

Received: 9 November 2021

Accepted: 14 December 2021

Published: 17 December 2021

Publisher's Note: MDPI stays neutral with regard to jurisdictional claims in published maps and institutional affiliations.

Copyright: (c) 2021 by the authors. Licensee MDPI, Basel, Switzerland. This article is an open access article distributed under the terms and conditions of the Creative Commons Attribution (CC BY) license (https:// creativecommons.org/licenses/by/ $4.0 /)$.
Cooperative Agricultural Research Center, Prairie View A\&M University, Prairie View, TX 77446, USA; aygeremew@pvamu.edu (A.G.); sewoldesenbet@pvamu.edu (S.W.); ccarpenter9@PVAMU.EDU (C.C.); epeace1@pvamu.edu (E.P.); adweerasooriya@PVAMU.EDU (A.W.)

* Correspondence: lecarson@pvamu.edu; Tel.: +1-936-261-5010
Abstract: With the ongoing climate change scenario and alarmingly increased land degradation, understanding complex interactions of drought stress and organic fertilizers on morpho-physiological traits and dynamics of nutrient concentration is pivotal for sustainable production leafy vegetables such as mustard (Brassica juncea). Thus, this study evaluated the effect of drought stress and organic fertilizers on $B$. juncea growth, physiology, and dynamics of nutrient concentration at the vegetative stage. The plants were exposed to three water stress levels (well-watered ( $100 \%$ field capacity, FC), mild ( $50 \%$ FC), and severe ( $25 \%$ FC) supplemented with three organic fertilizers (chitosan, ultra green, and home-grown natural vegetable foods) either individually or in combination during the vegetative growth stage. Water stress had a negative effect on growth and physiological traits, and macro- and micronutrients of mustard. However, the ameliorative effects of fertilizer application were revealed by improved plant height, leaf area, relative water content, membrane stability index, and chlorophyll content from $9.7 \%$ to $26.9 \%, 28 \%$ to $32.72 \%, 7.97 \%$ to $39.51 \%, 7.93 \%$ to $39.66 \%$, and $29.68 \%$ to $56.53 \%$, respectively. Analysis of variance revealed a significant effect of soil moisture level, fertilizer type and their interaction on content of macronutrients $(\mathrm{Ca}, \mathrm{K}, \mathrm{P}, \mathrm{N}, \mathrm{C}, \mathrm{S}, \mathrm{Na}, \mathrm{Mg})$ and micronutrients $(\mathrm{Fe}, \mathrm{Zn}$ ) in mustard leaves. However, there was no significant effect detected for $\mathrm{Cu}$ across all factors as well the interaction effect on $\mathrm{Mn}$. Overall, our results indicated that application of organic fertilizers enables mustard plant to withstand the deleterious effect of drought stress, resulting in improved growth and physiological traits as well as leaf nutrient content.

Keywords: mustard; drought; fertilizers; macronutrients; micronutrients; growth; interaction

\section{Introduction}

The Indian mustard (Brassica juncea L.) is an economically valuable plant widely consumed for its green vegetables, seed oil, and medicinal value. The species is a remarkable source of several macro- and micronutrients and nutraceuticals which are used to prevent and cure an array of chronic and non-communicable diseases [1-3]. Despite these economic and health benefits, low water availability and poor soil fertility during vital stages of its seed germination, growth, flowering, and pod filling severely impact crop yield [4-6]. For example, Chauhan et al. [7] reported a yield decline differing between $17 \%$ and $94 \%$ in mustard under drought stress. Nevertheless, plant growth and crop productivity may be adversely altered depending on the genotype, plant phenological stage, as well as intensity, timing, and duration of water stress [8,9].

Plants face uninterrupted fluxes of environmental conditions and are frequently subjected to abiotic stresses such as drought (water deficit) and nutrient imbalance [9]. Drought stress is regarded as one of the most major abiotic stresses, triggering an impediment in several crops' growth and production worldwide [6,10-14] and its intensity is predicted 
to increase in the future under the changing climate conditions $[15,16]$. Drought stress has an effect on the vegetative and reproductive stages of mustard growth including seed germination, branching, flowering, seed yield, and seed weight [8]. At the vegetative stage, it affects cell expansion and division, thus affecting leaf expansion [8]. Drought disrupts the supply of vital nutrients in the soil, reducing or triggering an imbalance in the nutritional elements in the plant tissue [16-18]. Studies have shown that during the vegetative stage, drought stress decreases the concentration of several nutrients content [19-21].

However, from a plants-soil perspective, the impacts of drought on soil moisture and plant productivity can be mitigated by application of fertilizers [22-24]. Application of organic fertilizers in plant is one of the fundamental pillars of sustainable agriculture [25]. Since the use of organic fertilizers provides essential nutrients and improves other soil properties, such as water-holding capacity, nutrient-holding capacity, and drought tolerance $[16,26,27]$; yet, different types of fertilizer contribute differently. For example, application of chitosan (a biodegradable polymer) stimulated plant growth and improved availability and uptake of water and essential nutrients [28]. Others have also claimed that application of organic fertilizers to meet a specific nutrient demand of crops may concomitantly boost the level of other plant nutrients $[29,30]$. While effects of fertilizer type and drought on crop growth and yield have been studied separately [5,31], little is known about the combined effect of these stressors on growth plasticity of $B$. juncea and nutrient dynamics across time within the vegetative stage. Quantifying the interactive effects of different irrigation levels and fertilizer types on the growth and macro- and micronutrients dynamics of $B$. juncea could provide paramount insight for developing more effective water management leading towards sustainable agriculture [32].

Crop yield and growth are not the only crucial traits regarded for breeding programs, but also sustaining and, if possible, increasing beneficial bioactive compounds and nutrients content is recommended for human use $[18,33,34]$. Hence, understanding of the dynamics and mechanisms involved in nutrient acquisition and distribution of edible plants like mustard with increased nutrient contents could open an avenue to develop improved plant varieties and alleviate malnutrition. Organically grown vegetables are progressively sought by health-conscious consumers [35] and as a result, small-scale vegetable growers are transitioning from conventional farming to more profitable organic farming $[36,37]$. Therefore, unraveling the effects of soil moisture level and organic fertilizer type on plant growth and dynamics in macro- and micronutrients in mustard could help to identify the harvest stage with the highest amount of nutrients available for healthy nutrition.

Overall, literatures only showed the separate effect of drought and organic fertilizers but not the details on the interactive effect of organic fertilizer types and drought on growth and dynamics of macro- and micronutrients in mustard leaves at the vegetative stage. It was hypothesized that the growth and dynamics of nutrients in leaves would vary under drought stress with and without application of organic fertilizers. The objective of this study was to unravel the interactive effect of water stress levels and organic fertilizer types on growth and temporal dynamics of macro- and micronutrients within the leaves of mustard (B. juncea) throughout the vegetative stage.

\section{Material and Methods}

\subsection{Plant Material and Growth Conditions}

The experiment was carried out in the greenhouse located at Bill and Vera Daniel Ranch and Farm, Prairie View A\&M University, Prairie View, TX, USA during Spring 2021. Seeds of the broad leaf mustard (Brassica juncea) were acquired from Twilley seed company (Hodges, SC, USA). Seven seeds were sown in plastic pots (12-inch size) containing $5 \mathrm{~kg}$ of $50 \%$ sand and $50 \%$ clay soil, with bulk density, electrical conductivity, and $\mathrm{pH}$ of $1.50 \mathrm{mg} \mathrm{m}^{-3}, 108 \mathrm{dS} \mathrm{m}^{-1}$, and 8.23, respectively, in the green house at Prairie View A\&M University. All seedlings were irrigated to the field capacity (FC) before the commencement of soil moisture deficit and fertilizer treatments. The seedlings were thinned by conserving three seedlings of the same vigor in each pot. The FC of the soil was determined using the 
gravimetric method [38]. The experimental design was a factorial experiment arranged in a split plot design. Two weeks after emergence, the plants were subjected to three soil moisture levels and three organic fertilizers treatments and were replicated three times in a split plot design.

The soil moisture levels were controlled at 100\% (well-watered, WW), 50\% (mild stress, MS), and $25 \%$ (severe stress, SS) of the FC which correspond to $16.5 \%, 8.75 \%$, and $4.41 \%$, respectively, of the soil moisture meter readings (Delta-T Devices Ltd., Cambridge, UK). Three fertilizers (20 mg each), namely chitosan $(\mathrm{CH})$ (Sigma) a natural polymer and biofertilizer or stimulant, ultra green (UG) all-purpose plant food (Pennington ${ }^{\circledR}$, Atlanta, GA, USA), and home-grown natural vegetable food (HO) (Dr. Earth Inc., Winters, CA, USA), were applied at the commencement of the soil moisture treatments. $\mathrm{CH}$ is a linear polysaccharide composed of randomly distributed $\beta$-linked D-glucosamine and $\mathrm{N}$-acetyl-D-glucosamine and used for soil amendment as biofertilizer and stimulant. UG is comprised of total nitrogen $(10 \%)$, available phosphate $(10 \%)$, soluble potash $(10 \%)$, calcium $(5 \%)$, magnesium $(0.8 \%)$, sulfur $(1 \%)$, copper $(0.05 \%)$, iron $(2 \%)$, manganese $(0.05 \%)$, and $\mathrm{Zn}$ $(0.05 \%)$. HO is composed of total nitrogen $(4 \%)$, available phosphate $(6 \%)$, soluble potash $(3 \%)$, calcium $(4.75 \%)$, beneficial soil microbes, and mycorrhizae. Soil moisture content was monitored on a daily basis through a gravimetric method and the plant was periodically watered (once every 2 days) to sustain the desired soil moisture level.

\subsection{Measurement of Growth}

Plant height was measured from the stem base of a plant to the tip of its shoot using a meter scale bi-weekly. Leaf area (LA) was calculated from measurements of leaf length (from the leaf base to the apex) and width (midpoint between the leaf base and the apex) applying the equation:

$$
\text { LA }\left(\mathrm{cm}^{2}\right)=0.72 * \text { length } * \text { width }
$$

where 0.72 is the correction factor for determination of leaf area in mustard adopted from Ramil and Sulaiman [39]. Individual plants that were not used for relative water content and nutrient analyses were selected to determine above-ground and below-ground biomass. Individual plants were separated into roots (for below-ground biomass) and shoots and leaves (for above-ground biomass) and were dried in an oven at $75 \pm 1{ }^{\circ} \mathrm{C}$ until their constant weights were acquired. These dried weights were their respective biomass values, i.e., below-ground biomass and above-ground biomass, respectively. Root to shoot ratio was determined based on above-ground biomass and below-ground biomass.

\subsection{Physiological Traits}

Chlorophyll contents in the intact leaves of mustard plants were measured using Chlorophyll meter, SPAD-502 (Minolta Co., Ltd., Osaka, Japan). The SPAD values were taken at the base of the leaf lamina, middle, and towards the tip. These values provide an indication of the relative amount of total chlorophyll present in plant leaves. The values were calculated according to the amount of light transmitted by the leaf area $(2 \times 3 \mathrm{~mm})$ in two wavelength regions in which the absorption of chlorophyll is different. Higher SPAD values signify higher total chlorophyll contents. The observations were made early in the morning between 9:00 and 11.00 a.m.

Relative water content (RWC) was determined by the modified method of Barrs and Weatherley [40]. In each treatment, fully expanded leaves were collected from individual plants and cut into $4 \mathrm{~mm}$ discs. Fresh weight (FW) of these discs was determined and then submersed in distilled water for $12 \mathrm{~h}$. Subsequently, the surface of the discs was blotted dry and saturated weight (SW) was recorded. Thereafter, the samples were dried in an oven at $65{ }^{\circ} \mathrm{C}$ for $24 \mathrm{~h}$ and DW was recorded. RWC in percent was then calculated as: $\mathrm{RWC}=((\mathrm{FW}-\mathrm{DW}) /(\mathrm{SW}-\mathrm{DW})) \times 100$.

Membrane stability index (MSI) was estimated following the approach of Sairam [41]. One half gram of sample comprising of 8 leaf sections, $5 \mathrm{~cm}$ long each, were soaked in distilled water and placed in a test tube with $20 \mathrm{~mL}$ of distilled water. The tubes were 
incubated overnight at room temperature. After incubation, the electrical conductivity of the water (C1) was measured using conductivity meter HI198129 (Hanna Instruments Inc., Woonsocket, Rhode Island). The samples were then boiled at $100{ }^{\circ} \mathrm{C}$ for $10 \mathrm{~min}$ and conductance was recorded (C2). Membrane stability was computed as:

$$
\mathrm{MSI}=(1-(\mathrm{C} 1 / \mathrm{C} 2)) \times 100
$$

\subsection{Leaf Macro- and Micronutrient Analysis}

Young leaves of mustard plant were obtained for macro- and micronutrient analysis after 30 and 60 days of treatments application. The leaves were freeze dried for $12 \mathrm{~h}$ to constant weight and were ground manually using mortar and pestle. For microwave digestion, about $250 \mathrm{mg}$ of each mustard leaves sample were directly placed into a microwave closed vessel. Then, $2 \mathrm{~mL}$ of $30 \% \mathrm{H}_{2} \mathrm{O}_{2}$ and $7.0 \mathrm{~mL}$ of $65 \%(\mathrm{~m} / \mathrm{m}) \mathrm{HNO}_{3}$ solutions were added to each vessel. The digestion of the samples was executed using a digester block Quimis (model TE 040/25) with equivalent temperature controller, up to 40 borosilicate microtubes and a high-pressure microwave oven (Milestone Ethos UP 1600, Sorisole, Italy) functioning at a frequency of $2450 \mathrm{~Hz}$, with an energy output of $900 \mathrm{~W}$. After the digestion and subsequent cooling, the digested samples were filtered through a $0.2-\mu \mathrm{m}$ nylon membrane (Millipore Sigma ${ }^{\mathrm{TM}}$ Millex $^{\mathrm{TM}}$-GP Sterile Syringe Filters, Burlington, Massachusetts).

The concentration of $\mathrm{P}, \mathrm{K}, \mathrm{Ca}, \mathrm{Cu}, \mathrm{Mg}, \mathrm{Fe}, \mathrm{Mn}, \mathrm{Na}$, and $\mathrm{Zn}$ in each sample was analyzed using radial view of Inductive Coupled Plasma Optical Emission Spectrometer (ICP-OES, Agilent ICP-5100) equipped with Agilent SP4 autosampler, standard DV torch (1.8 mm ID injector), concentric sea spray nebulizer type, standard double-pass glass cyclonic spray chamber, and supplied with ultrapure argon gas. For this analysis, calibration standard solutions ranging from 0 to $500 \mathrm{ppm}$, from single element $(\mathrm{P}, \mathrm{K}, \mathrm{Ca}, \mathrm{Cu}, \mathrm{Mg}, \mathrm{Fe}, \mathrm{Mn}, \mathrm{Na}$, and $\mathrm{Zn}$ ) and multi-element (Lu; Sigma-Aldrich, Saint Louis, Missouri, USA) were prepared. The analyses were performed under the instrumental variables of $1.2 \mathrm{~kW}$ radio frequency power, $12 \mathrm{~L} \mathrm{~min}^{-1}$ plasma gas flow rate, $1.0 \mathrm{~L} \mathrm{~min}^{-1}$ auxiliary gas flow rate, $1.0 \mathrm{~L} \mathrm{~min}^{-1}$ sample uptake rate, $0.7 \mathrm{~L} \mathrm{~min}^{-1}$ nebulizer gas flow rate, and $5 \mathrm{~s}$ read time. Emission lines that displayed low interference, high analytical signal, and background ratios were chosen for each element with $\mathrm{Ca}$ at 315.887, $\mathrm{Cu}$ at 324.754, Fe at 238.204, $\mathrm{Mg}$ at 285.213, $\mathrm{K}$ at 766.491, $\mathrm{Mn}$ at 257.610, $\mathrm{Na}$ at 589.592, $\mathrm{P}$ at 214.914, and $\mathrm{Zn}$ at $213.857 \mathrm{~nm}$ with a modification of Kebrom [30]. The correlation coefficient for the calibration curves was $>0.9990$, with a readback error of $<0.5 \%$. All solutions were analyzed in triplicate. Mustard leaf samples (30 mg grounded) were obtained and rolled in aluminum foil. The CHNS Analyzer Flash Elemental Analyzer was used to determine the percentages of carbon, hydrogen, nitrogen, and sulfur, through complete and instant oxidation of the mustard leaves by flash combustion.

\subsection{Statistical Analysis of the Data}

Data were computed by analysis of variance (ANOVA), with treatments as the independent variable using R v3.5 [42] and the agricolae package [43]. Tukey multiple comparison test (significance level 5\%) was used to calculate the differences between each factor. All values were expressed as mean values. A correlation analysis was executed to study the relationship between multiple traits. The general linear model was computed using the software Statistica 12.0. The Akaike's Information Criterion (AIC) was used to identify the best fit model (with the lowest AIC score) interpreting the interactive effect of the treatments at the significance level of $p \leq 0.05$ and $p \leq 0$. 001. The effect of all variables was performed by Wald statistics to estimate the significance of the regression coefficient. The contribution of each variable relative to others in the model was assessed using the likelihood ratio test that reports the log-likelihoods for the model that includes a particular effect and all effects that precede it. The incremental Wald ChiSquare $\left(\chi^{2}\right)$ provides a test of the change in the log-likelihood that is attributable to each individual effect. 


\section{Results and Discussion}

\subsection{Interactive Effects of Drought and Organic Fertilizers on Growth and Physiological Traits}

Drought stress had a highly significant $(p \leq 0.01)$ effect on growth (leaf area and height), shoot dry weight, and physiological (relative water content, chlorophyll content, and membrane stability) traits of Brassica juncea plants at the vegetative stage (Table 1). Significant interactions of soil moisture and fertilizer types $(p \leq 0.01)$ were also recorded for all morpho-physiological traits except for root biomass (Table 2; $R^{2}=0.49$, Table S1). Concurrent with our results, water stress was shown to reduce plant height and leaf area in wild mustard and brassica species $[44,45]$ and other plant species $[46,47]$. The impairment of mitosis and the elongation and expansion of cells as well as the down of turgor pressure caused by moisture stress result in reduced leaf area and growth $[9,48,49]$. Additionally, a decline in leaf area, has been regarded as a morphological acclimatization mechanism to lessen water loss through transpiration. Optimal leaf area is critical for photosynthesis, which in turn, is the main driver of plant growth $[9,50]$. The effect of water stress significantly decreased the shoot dry weight and root dry weight by $76.2 \%$ and $74.9 \%$, respectively (Table 1). Other Brassica species have also shown reduction in dry matter production under water deficit condition largely due to its inhibitory effect on leaf development and consequently light interception and reduced carbon assimilation [51].

Table 1. Effects of drought stress and organic fertilizer application on morpho-physiological traits of B. juncea.

\begin{tabular}{|c|c|c|c|c|c|c|c|c|c|}
\hline Fertilizer & $\begin{array}{c}\text { Soil } \\
\text { Moisture }\end{array}$ & SPAD & RWC (\%) & $\begin{array}{l}\text { Height } \\
\text { (cm) }\end{array}$ & $\mathrm{LA}\left(\mathrm{cm}^{2}\right)$ & MSI (\%) & $\begin{array}{c}\text { Shoot } \\
\text { Biomass (g) }\end{array}$ & $\begin{array}{c}\text { Root } \\
\text { Biomass (g) }\end{array}$ & RSR \\
\hline \multirow{3}{*}{ Control } & WW & $46.82^{a}$ & $50.44^{\mathrm{a}}$ & $59.13^{a}$ & $50.09^{a}$ & $75.09^{a}$ & $22.44^{\mathrm{a}}$ & $19.12^{\mathrm{a}}$ & $0.85^{a}$ \\
\hline & MS & $38.19^{b}$ & $45.53^{b}$ & $57.40^{\mathrm{a}}$ & $38.16^{b}$ & $62.95^{b}$ & $15.09^{b}$ & $11.66^{\mathrm{b}}$ & $0.78^{a}$ \\
\hline & SS & $21.75^{c}$ & $32.57^{c}$ & $40.91^{b}$ & $31.82^{c}$ & $37.37^{c}$ & $5.34^{\mathrm{c}}$ & $4.8^{\mathrm{c}}$ & $0.91^{\mathrm{a}}$ \\
\hline \multirow{3}{*}{$\mathrm{CH}$} & WW & $58.82^{\mathrm{a}}$ & $90.49^{a}$ & $59.88^{a}$ & $47.09^{a}$ & $69.11^{\mathrm{a}}$ & $34.96^{\mathrm{a}}$ & $17.78^{a}$ & $0.51^{b}$ \\
\hline & MS & $43.74^{b}$ & $48.52^{b}$ & $57.06^{\mathrm{ab}}$ & $38.16^{b}$ & $61.03^{b}$ & $23.84^{b}$ & $13.91^{b}$ & $0.59^{b}$ \\
\hline & SS & $36.64^{c}$ & $35.39^{c}$ & $54.69^{b}$ & $32.1^{c}$ & $40.59^{c}$ & $12.51^{\mathrm{c}}$ & $18.59^{a}$ & $1.51^{\mathrm{a}}$ \\
\hline \multirow{3}{*}{$\mathrm{HO}$} & WW & $52.26^{a}$ & $97.18^{a}$ & $59.38^{a}$ & $51.08^{a}$ & $89.88^{a}$ & $25.08^{a}$ & $7.73^{b}$ & $0.31^{b}$ \\
\hline & MS & $41.95^{b}$ & $76.75^{b}$ & $55.65^{b}$ & $46.97^{b}$ & $70.21^{b}$ & $16.12^{b}$ & $4.64^{\mathrm{c}}$ & $0.29^{b}$ \\
\hline & SS & $30.93^{c}$ & $53.84^{\mathrm{c}}$ & $52.45^{c}$ & $33.15^{c}$ & $53.86^{c}$ & $8.66^{c}$ & $13.52^{\mathrm{a}}$ & $1.58^{\mathrm{a}}$ \\
\hline \multirow{3}{*}{ UG } & WW & $60.13^{a}$ & $88.51^{\mathrm{a}}$ & $59.79^{a}$ & $64.5^{6} \mathrm{a}$ & $53.17^{\mathrm{a}}$ & $28.72^{\mathrm{a}}$ & $13.68^{b}$ & $0.48^{b}$ \\
\hline & MS & $53.78^{b}$ & $66.81^{b}$ & $57.05^{b}$ & $52.77^{\mathrm{b}}$ & $46.17^{b}$ & $19.07^{b}$ & $20.48^{a}$ & $1.08^{a}$ \\
\hline & SS & $39.95^{c}$ & $49.01^{c}$ & $55.97^{c}$ & $47.3^{5 c}$ & $40.62^{c}$ & $12.25^{c}$ & $5.98^{c}$ & $0.49^{b}$ \\
\hline \multirow{3}{*}{$\mathrm{CH}+\mathrm{HO}$} & WW & $65.87^{a}$ & $86.74^{a}$ & $61.53^{a}$ & $55.39^{a}$ & $74.12^{\mathrm{a}}$ & $30.44^{\mathrm{a}}$ & $4.92^{\mathrm{c}}$ & $0.16^{c}$ \\
\hline & MS & $55.76^{b}$ & $64.31^{b}$ & $58.63^{b}$ & $45.85^{b}$ & $64.84^{\mathrm{b}}$ & $19.71^{b}$ & $9.44^{b}$ & $0.48^{b}$ \\
\hline & SS & $46.68^{c}$ & $42.64^{c}$ & $54.47^{\mathrm{c}}$ & $39.51^{c}$ & $40.92^{c}$ & $10.32^{c}$ & $13.94^{\mathrm{a}}$ & $1.35^{\mathrm{a}}$ \\
\hline \multirow{3}{*}{$\mathrm{CH}+\mathrm{UG}$} & WW & $59.64^{\mathrm{a}}$ & $96.46^{\mathrm{a}}$ & $69.46^{\mathrm{a}}$ & $52.01^{a}$ & $84.75^{a}$ & $27.15^{a}$ & $10.96^{\mathrm{a}}$ & $0.41^{\mathrm{a}}$ \\
\hline & MS & $44.36^{\mathrm{b}}$ & $70.85^{b}$ & $59.77^{b}$ & $45.92^{b}$ & $65.63^{b}$ & $21.02^{b}$ & $3.26^{c}$ & $0.16^{b}$ \\
\hline & SS & $31.58^{c}$ & $43.86^{c}$ & $45.29^{c}$ & $38.88^{c}$ & $54.09^{c}$ & $13.51^{\mathrm{c}}$ & $7.34^{b}$ & $0.55^{a}$ \\
\hline \multirow{3}{*}{$\mathrm{HO}+\mathrm{UG}$} & WW & $65.54^{\mathrm{a}}$ & $83.03^{a}$ & $60.44^{\mathrm{a}}$ & $53.19^{a}$ & $66.34^{\mathrm{a}}$ & $26.45^{\mathrm{a}}$ & $17.09^{\mathrm{a}}$ & $0.65^{b}$ \\
\hline & MS & $54.56^{\mathrm{b}}$ & $60.88^{b}$ & $59.93^{b}$ & $42.37^{b}$ & $50.82^{b}$ & $16.42^{b}$ & $11.94^{\mathrm{b}}$ & $0.73^{b}$ \\
\hline & SS & $39.59^{c}$ & $46.78^{c}$ & $53.00^{b}$ & $36.63^{c}$ & $41.04^{c}$ & $14.05^{\mathrm{c}}$ & $5.98^{\mathrm{c}}$ & $1.48^{\mathrm{a}}$ \\
\hline \multirow{3}{*}{$\begin{array}{l}\mathrm{CH}+\mathrm{UG} \\
+\mathrm{HO}\end{array}$} & WW & $76.66^{a}$ & $92.59^{a}$ & $77.44^{\mathrm{a}}$ & $68.62^{a}$ & $85.18^{a}$ & $35.53^{a}$ & $26.28^{a}$ & $0.74^{b}$ \\
\hline & MS & $61.74^{b}$ & $78.58^{b}$ & $61.47^{\mathrm{b}}$ & $58.58^{b}$ & $74.31^{\mathrm{b}}$ & $24.52^{b}$ & $12.75^{\mathrm{b}}$ & $0.52^{c}$ \\
\hline & SS & $50.04^{c}$ & $41.82^{\mathrm{c}}$ & $55.35^{c}$ & $44.53^{c}$ & $61.93^{c}$ & $12.92^{\mathrm{c}}$ & $14.14^{\mathrm{b}}$ & $1.09^{a}$ \\
\hline
\end{tabular}

Different letters denote significant difference $(p \leq 0.05)$ among soil moisture levels while treated with a particular fertilizer or combined ones. $\mathrm{CH}=$ chitosan, $\mathrm{UG}=$ ultra-green, $\mathrm{HO}=$ home-grown organic nutrition, $\mathrm{SS}=$ severe stress, $\mathrm{MS}=$ moderate stress, $\mathrm{WW}=$ well-watered, $\mathrm{RWC}=$ relative water content, $\mathrm{LA}=$ leaf area, $\mathrm{MSI}=$ membrane stability index, and RSR $=$ root to shoot ratio.

Despite a general decline in plant height, leaf area, and shoot dry weight being observed along with soil moisture levels, the application of organic fertilizers improved these traits. Compared to the control, under severe drought stress, plant height and leaf area increased in the mixed fertilizer treatments, chitosan, and home-grown organic nutrient $(\mathrm{CH}+\mathrm{HO})$ by $33.14 \%$ and $24.2 \%$, $\mathrm{HO}$ and ultra-green, $\mathrm{UG}(\mathrm{HO}+\mathrm{UG})$ by $29.6 \%$ and $15.11 \%$, and chitosan $(\mathrm{CH})+\mathrm{UG}+\mathrm{HO}$ by $35.3 \%$ and $55.6 \%$, respectively (Table 1 ). 
Combined effects of drought and fertilizer types increased leaf area and height per plant with a greater magnitude than under drought stress alone, and this increase by combined drought stress and fertilizer types was synergistic too (Table S1). The positive response of plant heights, leaf area, and shoot biomass in the mixed fertilizer treatments under severe water stress condition might partly be due to the augmented nutrient level. This could also partly be because of the better quality of organic matter by the addition of organic fertilizers, which conceivably increased the absorbing ability of the root systems for nutrients [52]. In agreement with our results, application of chitosan stimulated plant growth and increased the availability and uptake of water and essential nutrients by alleviating drought stress [28,53]. In addition, it has been found that organic fertilizers modulate nutrients mobility and availability under varying soil water conditions thus ultimately enhancing plant growth [54,55]. In agreement with our results, it has been reported that application of chitosan reduced the negative impact of drought condition on dry matter [11] and growth attributes [56,57]. However, application of fertilizers increased either shoot weight or dry weight at a different magnitude. In the mixed fertilizer and well-watered treatments, the highest shoot dry weight was acquired, and this signifies that mustard favors the regular application of water and fertilizers for optimum growth and development.

Table 2. Analysis of variance (ANOVA) results for the effect of soil moisture, fertilizer types, and their interaction on morpho-physiological traits of B. juncea.

\begin{tabular}{|c|c|c|c|c|c|c|c|c|c|}
\hline \multirow{3}{*}{ Parameters } & \multicolumn{9}{|c|}{ Sources of Variation } \\
\hline & \multicolumn{3}{|c|}{ Fertilizers } & \multicolumn{3}{|c|}{ Soil Moisture } & \multicolumn{3}{|c|}{ Fertilizers * Soil Moisture } \\
\hline & DF & SS & Prob $>$ F & DF & SS & Prob $>$ F & DF & SS & Prob $>$ F \\
\hline SPAD & 7 & 905.744 & $<0.0001 * *$ & 2 & 6458.04 & $<0.0001^{* *}$ & 14 & 255.85 & $<0.0001^{* *}$ \\
\hline RWC & 7 & 4731.75 & $<0.0001 * *$ & 2 & 21617.94 & $<0.0001^{* *}$ & 14 & 2228.57 & $<0.0001^{* *}$ \\
\hline Height & 7 & 917.51 & $<0.0001 * *$ & 2 & 1741.39 & $<0.0001^{* *}$ & 14 & 908.06 & $<0.0001^{* *}$ \\
\hline LA & 7 & 633.25 & $<0.0001 * *$ & 2 & 3629.51 & $<0.0001^{* *}$ & 14 & 185.23 & $<0.0001^{* *}$ \\
\hline MSI & 7 & 2769.62 & $<0.0001 * *$ & 2 & 9428.19 & $<0.0001^{* *}$ & 14 & 810.53 & $<0.0001 * *$ \\
\hline Shoot biomass & 7 & 445.41 & $<0.0001 * *$ & 2 & 4286.30 & $<0.0001^{* *}$ & 14 & 137.36 & $0.0014^{* *}$ \\
\hline Root biomass & 7 & 2404.56 & $0.002 * *$ & 2 & 662.95 & $0.031 *$ & 14 & 1771.81 & 0.1784 \\
\hline RSR & 7 & 2.141 & $0.007^{* *}$ & 2 & 4.59 & $<0.0001 * *$ & 14 & 5.02 & $0.0003^{* *}$ \\
\hline
\end{tabular}

$\mathrm{DF}=$ degree of freedom, SS = sum of squares, RWC = relative water content, LA = leaf area, MSI = membrane stability index, and RSR = root to shoot ratio. ${ }^{* *}=$ highly significantly $(p \leq 0.01)$ and ${ }^{*}=$ as significantly $(p \leq 0.05)$ different.

There was a significant general trend in decreasing of relative water content (RWC), membrane stability index (MSI), and chlorophyll content (SPAD) of mustard plants along with soil moisture stress intensity $(p<0.05$, Table 1$)$. However, overall, the application of fertilizers significantly increased the leaf RWC (28.41\%), MSI (75.31\%), and chlorophyll content $(55.5 \%)$ under severe water stress condition as the case in the mixed fertilizers $(\mathrm{CH}+\mathrm{UG}+\mathrm{HO})$ relative to the control suggesting a synergistic response. This synergetic effect was also supported by our generalized regression model, which revealed a significant interaction effect on MSI (Wald- $\chi 2=236.71, p \leq 0.001$ ) and RWC (Wald- $\chi 2=29.92$, $p \leq 0.001)$ when comparing the combined $(\mathrm{CH}+\mathrm{UG}+\mathrm{HO})$ effect over a single effect of UG (Table S1). Looking at the effect of individual stress factors, soil moisture deficit induced significant decrease in RWC (35.43\%), MSI (50.23\%), and SPAD (45\%) (Table 1). Overall, the effects of combined fertilizers and drought stress on RWC, SPAD, and MSI were stronger than the effects of individual stress factors (Table 1), but the level of the effect varied. Lower RWC by B. juncea show its predisposition to drought stress that could be coupled with a discrepancy between water loss and water uptake and is a signal of the decline in turgor pressure of guard cells due to stomata closure [58,59]. In addition, the lower RWC reflects considerable reductions of leaf water potential, which ultimately lead to closure of stomata. This, in turn, favors stomatal resistance that could potentially reduce the rate of transpiration and an increase in leaf temperature [60]. Consequently, 
higher temperature reduces membrane stability and permeability and, ultimately, different aspects of plant metabolism. Higher RWC in organic fertilizers treated plants might be due to improved water holding capacity [61] and osmolytes as supported by the increase MSI. The decrease in MSI may be because under water deficit conditions the overproduction of reactive oxygen species (ROS) occurs, which disrupts the cell membrane by altering its phospholipid and fatty acid compositions [62]. Hence, the ability of a plant to maintain MSI and integrity would explain its tolerance toward drought [63].

Chlorophyll content has been used as a proxy to determine the tolerance of plants to water stress [64]. In the present study, chlorophyll content progressively decreased by $45 \%$ (from 46.82 to 25.75 when the mustard plants were exposed to drought stress) (Table 1). This reduction in SPAD could be associated with oxidative damage of chlorophyll pigment complexes and light-harvesting proteins modulating chlorophyll synthesis $[65,66]$. Aligned with our results, drought-induced reductions in chlorophyll contents are quite common in Brassica species and cultivars [51]. In contrast, some studies have shown increased chlorophyll content under moderate and intensive drought stress $[67,68]$. However, application of fertilizer either singly or in mix improved the total chlorophyll content under severe drought stress compared to the control (Table 1). Under severe water deficit condition, the maximum SPAD recorded was about 46.68 when treated with mix of $\mathrm{CH}$ and HGON. Our results showed a significant coupling effect of water stress and organic fertilizers on the chlorophyll content, based on SPAD measurements (Table 1). Application of organic fertilizers further promoted accumulation of chlorophyll content in plants [69]. Other studies have also shown that increasing chlorophyll content by organic fertilizer treatments under drought stress conditions may be due to increased activity of drought responsive enzymes [68]. The highest chlorophyll content of $B$. juncea plants under drought stress was observed in combined fertilizer treatment that could be due to positive effects of fertilizers that enhance $\mathrm{N}$ supply. It has been indicated that the formation of photosynthetic pigments mainly relies on the available nitrogen content in plants [70]. The higher amounts of chlorophyll could be correlated with the content of nitrogen $(r=0.91)$, which stimulates the chlorophyll biosynthesis process [71].

\subsection{Interactive Effects of Drought and Organic Fertilizer on Nutrients Content}

Analysis of variance revealed a significant effect of soil moisture level, fertilizer type, and their interaction on content of macronutrients ( $\mathrm{Ca}, \mathrm{K}, \mathrm{P}, \mathrm{N}, \mathrm{C}, \mathrm{S}, \mathrm{Na}, \mathrm{Mg}$ ) and micronutrients $(\mathrm{Fe}, \mathrm{Zn})$ in mustard leaves $(p<0.001$, Tables 4,5 and Table S1). However, there was not a significant effect detected for $\mathrm{Cu}$ across all factors (Table 1) as well the interaction effect on Mn. Drought stress and associated reduction in soil moisture can reduce plant nutrient uptake by reducing nutrient supply through mineralization [72], but also by reducing nutrient diffusion and mass flow in the soil [73]. The decline in the diffusion rate of nutrients towards the roots and their transport to the shoots could be due to the concurrent declines in membrane stability recorded. Although water stress without application of fertilizers decreased the content of all the macronutrients studied contrastingly, the $\mathrm{K}$ content was increased by $62.56 \%$ (Table 3). Etienne et al. [21] also reported that drought stress during the vegetative stage induces an increase in the concentration of $\mathrm{K}$ in leaves. Under water deficit conditions, maintaining sufficient $\mathrm{K}$ status may facilitate osmotic adjustment that enhances higher turgor pressure and RWC [74]. Nevertheless, the decline in RWC in the present study did not support this presumption. Thus, alternatively, the increase in leaf $\mathrm{K}$ content could be associated with its critical role in overcoming drought-induced oxidative damage via inhibition of reactive oxygen species (ROS) production [75]. In addition, drought stress caused a significant $(p \leq 0.05)$ decrease in the Na concentration in the leaves despite fertilizer application. However, our results also revealed a contrasting pattern between $\mathrm{K}$ and $\mathrm{Na}$ content in response to severe water stress $(r=-0.86, p \leq 0.01)$. It has been thought that Na content may up- or downregulate the function and accumulation of other compounds or nutrients such as $\mathrm{K}$ involved in osmotic adaptation [21,76]. The ionomic content of vegetative tissue can be influenced in 
a very unclear way by mineral uptake and availability as well as by drought [21], which supports our results.

Table 3. Effects of drought stress and organic fertilizer application on macro- and micronutrients of B. juncea.

\begin{tabular}{|c|c|c|c|c|c|c|c|c|c|c|}
\hline \multirow{2}{*}{ Fertilizers } & \multirow{2}{*}{$\begin{array}{c}\text { Soil } \\
\text { Moisture }\end{array}$} & \multicolumn{5}{|c|}{ Macronutrients (mg/mL) } & \multicolumn{4}{|c|}{ Micronutrients (mg/mL) } \\
\hline & & $\mathrm{Ca}$ & $\mathbf{K}$ & $\mathrm{Mg}$ & $\mathrm{Na}$ & $\mathbf{P}$ & $\mathrm{Cu}$ & Fe & Mn & Zn \\
\hline \multirow{3}{*}{ Control } & WW & $31.35^{\mathrm{a}}$ & $33.51^{\mathrm{c}}$ & $11.52^{\mathrm{a}}$ & $10.95^{b}$ & $9.81^{\mathrm{a}}$ & $0.07^{\mathrm{a}}$ & $1.78^{\mathrm{a}}$ & $0.42^{\mathrm{a}}$ & $0.50^{\mathrm{a}}$ \\
\hline & MS & $24.81^{b}$ & $43.84^{\mathrm{b}}$ & $7.63^{b}$ & $15.03^{\mathrm{a}}$ & $7.25^{b}$ & $0.04^{b}$ & $1.26^{\mathrm{a}}$ & $0.29^{b}$ & $0.414^{b}$ \\
\hline & SS & $11.03^{\mathrm{c}}$ & $54.47^{\mathrm{a}}$ & $4.55^{\mathrm{c}}$ & $7.12^{\mathrm{c}}$ & $3.38^{\mathrm{c}}$ & $0.03^{c}$ & $0.56^{\mathrm{b}}$ & $0.23^{c}$ & $0.23^{c}$ \\
\hline \multirow{3}{*}{$\mathrm{CH}$} & WW & $25.35^{\mathrm{a}}$ & $63.09^{\mathrm{a}}$ & $13.83^{\mathrm{a}}$ & $4.32^{c}$ & $14.58^{\mathrm{a}}$ & $0.07^{\mathrm{a}}$ & $3.90^{\mathrm{a}}$ & $0.08^{\mathrm{a}}$ & $0.94^{\mathrm{a}}$ \\
\hline & MS & $16.13^{b}$ & $57.83^{a}$ & $7.98^{b}$ & $12.07^{\mathrm{b}}$ & $11.32^{b}$ & $0.06^{a b}$ & $1.47^{\mathrm{b}}$ & $0.37^{a b}$ & $0.69^{\mathrm{a}}$ \\
\hline & SS & $12.11^{\mathrm{c}}$ & $43.69^{c}$ & $4.24^{\mathrm{c}}$ & $16.11^{\mathrm{a}}$ & $6.96^{c}$ & $0.05^{b}$ & $0.92^{b}$ & $0.23^{b}$ & $0.58^{\mathrm{a}}$ \\
\hline \multirow{3}{*}{$\mathrm{HO}$} & WW & $26.17^{a}$ & $94.62^{\mathrm{a}}$ & $26.79^{a}$ & $13.48^{\mathrm{a}}$ & $13.17^{\mathrm{a}}$ & $0.09^{a}$ & $7.19^{a}$ & $0.51^{\mathrm{a}}$ & $0.82^{\mathrm{a}}$ \\
\hline & MS & $21.12^{b}$ & $68.24^{b}$ & $15.13^{b}$ & $9.34^{b}$ & $11.00^{b}$ & $0.06^{a b}$ & $1.43^{\mathrm{b}}$ & $0.32^{\mathrm{a}}$ & $0.74^{\mathrm{ab}}$ \\
\hline & SS & $15.76^{\mathrm{c}}$ & $59.06^{c}$ & $10.11^{\mathrm{c}}$ & $4.07^{\mathrm{c}}$ & $8.69^{c}$ & $0.05^{b}$ & $0.96^{b}$ & $0.22^{\mathrm{a}}$ & $0.65^{b}$ \\
\hline \multirow{3}{*}{ UG } & WW & $31.35^{\mathrm{a}}$ & $91.51^{b}$ & $33.08^{a}$ & $17.82^{\mathrm{a}}$ & $15.07^{\mathrm{a}}$ & $0.09^{a}$ & $1.95^{\mathrm{a}}$ & $0.39^{a}$ & $0.72^{\mathrm{a}}$ \\
\hline & MS & $24.81^{b}$ & $83.94^{b}$ & $23.21^{b}$ & $12.47^{b}$ & $9.65^{b}$ & $0.07^{a b}$ & $1.64^{\mathrm{a}}$ & $0.35^{\mathrm{ab}}$ & $0.65^{\mathrm{a}}$ \\
\hline & SS & $11.03^{c}$ & $104.14^{\mathrm{a}}$ & $13.47^{\mathrm{c}}$ & $7.45^{c}$ & $6.76^{c}$ & $0.06^{b}$ & $1.45^{\mathrm{a}}$ & $0.28^{b}$ & $0.49^{b}$ \\
\hline \multirow{3}{*}{$\mathrm{CH}+\mathrm{HO}$} & WW & $18.53^{a}$ & $46.84^{\mathrm{C}}$ & $14.18^{\mathrm{a}}$ & $8.59^{c}$ & $12.53^{\mathrm{a}}$ & $0.87^{\mathrm{a}}$ & $3.90^{\mathrm{a}}$ & $0.38^{a}$ & $0.92^{\mathrm{a}}$ \\
\hline & MS & $16.56^{b}$ & $63.0^{\mathrm{b}}$ & $8.23^{b}$ & $12.84^{b}$ & $12.19^{a}$ & $0.06^{b}$ & $1.82^{b}$ & $0.29^{a b}$ & $0.59^{b}$ \\
\hline & SS & $13.26^{\mathrm{c}}$ & $92.08^{a}$ & $5.75^{\mathrm{c}}$ & $19.62^{\mathrm{a}}$ & $4.63^{b}$ & $0.05^{b}$ & $0.78^{b}$ & $0.19^{b}$ & $0.47^{b}$ \\
\hline \multirow{3}{*}{$\mathrm{CH}+\mathrm{UG}$} & WW & $35.68^{a}$ & $71.09^{a}$ & $16.90^{\mathrm{a}}$ & $14.54^{\mathrm{a}}$ & $13.55^{\mathrm{a}}$ & $0.11^{\mathrm{a}}$ & $4.42^{\mathrm{a}}$ & $0.54^{\mathrm{a}}$ & $0.54^{b}$ \\
\hline & MS & $26.23^{b}$ & $56.40^{b}$ & $9.33^{b}$ & $9.31^{b}$ & $11.28^{b}$ & $0.01^{b}$ & $2.91^{\mathrm{ab}}$ & $0.41^{\mathrm{ab}}$ & $0.67^{\mathrm{ab}}$ \\
\hline & SS & $16.19^{c}$ & $53.89^{b}$ & $6.09^{c}$ & $5.13^{c}$ & $10.29^{b}$ & $0.06^{b}$ & $1.23^{b}$ & $0.25^{b}$ & $0.88^{\mathrm{a}}$ \\
\hline \multirow{3}{*}{$\mathrm{HO}+\mathrm{UG}$} & WW & $29.27^{a}$ & $82.61^{a}$ & $28.63^{a}$ & $16.26^{\mathrm{a}}$ & $14.60^{\mathrm{a}}$ & $0.07^{b}$ & $3.82^{\mathrm{a}}$ & $0.43^{a}$ & $0.57^{\mathrm{b}}$ \\
\hline & MS & $21.79^{b}$ & $81.89^{a}$ & $14.29^{b}$ & $10.67^{b}$ & $11.63^{b}$ & $0.26^{\mathrm{a}}$ & $1.53^{\mathrm{ab}}$ & $0.28^{a b}$ & $0.64^{\mathrm{a}}$ \\
\hline & SS & $15.84^{\mathrm{c}}$ & $71.84^{b}$ & $7.97^{c}$ & $10.61^{b}$ & $7.57^{c}$ & $0.04^{b}$ & $0.66^{b}$ & $0.21^{b}$ & $0.68^{a}$ \\
\hline \multirow{3}{*}{$\begin{array}{c}\mathrm{CH}+\mathrm{UG}+ \\
\mathrm{HO}\end{array}$} & WW & $29.42^{\mathrm{a}}$ & $70.72^{c}$ & $13.95^{\mathrm{a}}$ & $18.95^{\mathrm{a}}$ & $13.09^{a}$ & $0.09^{a}$ & $5.28^{\mathrm{a}}$ & $0.42^{\mathrm{a}}$ & $0.69^{\mathrm{a}}$ \\
\hline & MS & $19.31^{b}$ & $81.36^{b}$ & $7.62^{b}$ & $8.81^{b}$ & $11.63^{a b}$ & $0.06^{\mathrm{a}}$ & $2.02^{b}$ & $0.34^{b}$ & $0.59^{b}$ \\
\hline & SS & $14.44^{\mathrm{c}}$ & $88.95^{a}$ & $4.23^{c}$ & $3.44^{\mathrm{c}}$ & $10.74^{b}$ & $0.06^{\mathrm{a}}$ & $0.76^{c}$ & $0.23^{c}$ & $0.54^{b}$ \\
\hline
\end{tabular}

Different letters denote significant difference $(p \leq 0.05)$ among soil moisture levels while treated with a particular fertilizer or combined ones. $\mathrm{CH}=$ chitosan, $\mathrm{UG}=$ ultra-green, $\mathrm{HO}=$ home-grown organic nutrition, $\mathrm{SS}=$ severe stress, $\mathrm{MS}=$ moderate stress, and WW = well-watered.

On the other hand, effects of combined fertilizers and water stress on macro- and micronutrients were stronger than the effects of individual stress factors, but the magnitude of effects varied for the specific nutrients (Tables 3-5). Though there was an improvement in $\mathrm{Mg}$ concentrations following application of organic fertilizers under severe soil moisture, a general decline was still observed along with soil moisture gradients. This pattern mirrors with the reduction in chlorophyll content (Table 3), as $\mathrm{Mg}$ plays a paramount role in chlorophyll synthesis [77]. In agreement with Chatelain et al.'s [78] report, in the present study, Mg concentrations were lower in the leaves of plants treated with chitosan. Ca decreased significantly in the leaves of mustard plants treated under severe water stress irrespective of fertilizers applied. This might be linked with restricted phloem mobility that negatively impacts the usual unidirectional transport of $\mathrm{Ca}$ during vegetative stage of the plant under water deficit conditions [79]. An increase in Ca contents in mixed fertilizers $(\mathrm{CH}+\mathrm{HO}, \mathrm{HO}+\mathrm{UG}, \mathrm{CH}+\mathrm{UG}$ and $\mathrm{CH}+\mathrm{UG}+\mathrm{HO})$ when compared with a single fertilizer $(\mathrm{CH}, \mathrm{HO}$, and $\mathrm{UG})$ suggests a synergetic effect (Table 3$)$. There was a general pattern in the decline of $\mathrm{N}$ and $\mathrm{P}$ contents along water stress levels with or without application of fertilizers (Table 3). Waraich et al. [80] have also indicated that plants decrease $\mathrm{N}$ and $\mathrm{P}$ uptake with a decrease in soil moisture. Importantly, a combination of fertilizers had a synergetic effect on phosphorus content when compared with the single effect of each fertilizer under severe water stress compared to the control (Table 3 and Table S1). The combined application of fertilizers $(\mathrm{CH}+\mathrm{UG}+\mathrm{HO})$ showed twofold $(68.53 \%)$ increase in $\mathrm{P}$ compared to the control under severe water stress. Application of organic fertilizers 
enhances uptake of macronutrients such as $\mathrm{N}$ and $\mathrm{P}$ in plants under different water stress levels $[9,81]$.

Table 4. Effects of drought stress and organic fertilizer application on nutrient (N, C, and S) content of $B$. juncea leaves at vegetative stage.

\begin{tabular}{|c|c|c|c|c|c|}
\hline \multirow{2}{*}{ Fertilizers } & \multirow{2}{*}{$\begin{array}{c}\text { Soil } \\
\text { Moisture }\end{array}$} & \multicolumn{3}{|c|}{$\%$ Nutrient Content } & \multirow{2}{*}{$\begin{array}{c}\text { Ratio } \\
\mathrm{C} / \mathrm{N}\end{array}$} \\
\hline & & N (\%) & $C(\%)$ & S (\%) & \\
\hline \multirow{3}{*}{ Control } & WW & $4.68^{\mathrm{a}}$ & $41.90^{b}$ & $1.66^{\mathrm{a}}$ & $9.05^{b}$ \\
\hline & MS & $3.18^{b}$ & $53.32^{a}$ & $1.09^{b}$ & $17.46^{\mathrm{a}}$ \\
\hline & SS & $1.56^{\mathrm{c}}$ & $30.52^{c}$ & $0.68^{c}$ & $19.97^{\mathrm{a}}$ \\
\hline \multirow{3}{*}{$\mathrm{CH}$} & WW & $6.01^{\mathrm{a}}$ & $67.90^{\mathrm{a}}$ & $1.97^{\mathrm{a}}$ & $11.3^{b}$ \\
\hline & MS & $4.40^{\mathrm{b}}$ & $53.32^{b}$ & $1.45^{\mathrm{a}}$ & $12.16^{\mathrm{b}}$ \\
\hline & SS & $1.71^{\mathrm{c}}$ & $33.19^{c}$ & $0.78^{\mathrm{b}}$ & $19.45^{\mathrm{a}}$ \\
\hline \multirow{3}{*}{$\mathrm{HO}$} & WW & $8.99^{\mathrm{a}}$ & $64.58^{a}$ & $3.22^{\mathrm{a}}$ & $7.42^{b}$ \\
\hline & MS & $6.24^{\mathrm{b}}$ & $57.50^{b}$ & $1.27^{\mathrm{b}}$ & $10.4^{\mathrm{b}}$ \\
\hline & SS & $2.53^{c}$ & $34.99^{c}$ & $0.79 \mathrm{~b}$ & $24.81^{\mathrm{a}}$ \\
\hline \multirow{3}{*}{ UG } & WW & $8.14^{\mathrm{a}}$ & $67.68^{a}$ & $2.21^{\mathrm{a}}$ & $5.53^{b}$ \\
\hline & MS & $5.11^{\mathrm{b}}$ & $43.86^{b}$ & $1.35^{\mathrm{ab}}$ & $6.51^{\mathrm{b}}$ \\
\hline & SS & $2.08^{c}$ & $33.98^{c}$ & $1.12^{\mathrm{b}}$ & $16.98^{a}$ \\
\hline \multirow{4}{*}{$\mathrm{CH}+\mathrm{HO}$} & WW & $9.04^{\mathrm{a}}$ & $66.56^{\mathrm{a}}$ & $1.90^{\mathrm{a}}$ & $7.19^{b}$ \\
\hline & MS & $4.30^{\mathrm{b}}$ & $44.10^{\mathrm{b}}$ & $1.81^{\mathrm{a}}$ & $11.19^{a b}$ \\
\hline & SS & $1.49^{c}$ & $34.44^{c}$ & $1.76^{\mathrm{a}}$ & $17.4^{\mathrm{a}}$ \\
\hline & WW & $8.02^{a}$ & $44.28^{a}$ & $1.83^{\mathrm{a}}$ & $7.23^{b}$ \\
\hline \multirow[t]{3}{*}{$\mathrm{CH}+\mathrm{UG}$} & MS & $5.50^{b}$ & $34.89^{b}$ & $1.33^{b}$ & $9.23^{a b}$ \\
\hline & SS & $1.92^{\mathrm{c}}$ & $31.62^{b}$ & $0.83^{c}$ & $13.94^{\mathrm{a}}$ \\
\hline & WW & $8.03^{a}$ & $68.51^{a}$ & $3.59^{\mathrm{a}}$ & $8.72^{b}$ \\
\hline \multirow[t]{3}{*}{$\mathrm{HO}+\mathrm{UG}$} & MS & $4.52^{\mathrm{b}}$ & $45.82^{b}$ & $2.19^{a b}$ & $10.32^{b}$ \\
\hline & SS & $1.73^{\mathrm{c}}$ & $35.99^{c}$ & $0.86^{\mathrm{b}}$ & $21.27^{\mathrm{a}}$ \\
\hline & WW & $7.80^{\mathrm{a}}$ & $55.41^{\mathrm{a}}$ & $2.38^{\mathrm{a}}$ & $8.34^{b}$ \\
\hline \multirow[t]{2}{*}{$\mathrm{CH}+\mathrm{UG}+\mathrm{HO}$} & MS & $3.82^{b}$ & $41.64^{b}$ & $1.20^{b}$ & $8.88^{b}$ \\
\hline & SS & $2.07^{\mathrm{b}}$ & $35.85^{b}$ & $0.72^{\mathrm{c}}$ & $17.27^{\mathrm{a}}$ \\
\hline
\end{tabular}

Different letters denote significant difference $(p<0.05)$ among soil moisture levels while treated with a particular fertilizer or combined ones. $\mathrm{CH}=$ chitosan, $\mathrm{UG}=$ ultra-green, $\mathrm{HO}=$ home-grown organic nutrition, $\mathrm{SS}=$ severe stress, MS = moderate stress, and WW = well-watered.

Table 5. Analysis of variance (ANOVA) results for the effect of soil moisture, fertilizer types, and their interaction on nutrient content of B. juncea leaves.

\begin{tabular}{|c|c|c|c|c|c|c|c|c|c|}
\hline \multirow{3}{*}{ Parameters } & \multicolumn{9}{|c|}{ Source of Variation } \\
\hline & \multicolumn{3}{|c|}{ Fertilizers } & \multicolumn{3}{|c|}{ Soil Moisture } & \multicolumn{3}{|c|}{ Fertilizers * Soil Moisture } \\
\hline & DF & SS & Prob $>F$ & DF & SS & Prob $>F$ & DF & SS & Prob $>F$ \\
\hline $\mathrm{K}$ & 7 & 9826.61 & $<0.0001^{* *}$ & 2 & 1060.73 & $<0.0001 * *$ & 14 & 7264.58 & $<0.0001^{* *}$ \\
\hline $\mathrm{Mg}$ & 7 & 1445.49 & $<0.0001^{* *}$ & 2 & 2019.11 & $<0.0001 * *$ & 14 & 325.93 & $<0.0001^{* *}$ \\
\hline $\mathrm{Na}$ & 7 & 706.64 & $<0.0001^{* *}$ & 2 & 50.44 & $<0.0001 * *$ & 14 & 1307.22 & $<0.0001 * *$ \\
\hline $\mathrm{Ca}$ & 7 & 709.38 & $<0.0001^{* *}$ & 2 & 2561.68 & $<0.0001 * *$ & 14 & 357.51 & $<0.0001^{* *}$ \\
\hline $\mathrm{Fe}$ & 7 & 55.04 & $0.0044 *$ & 2 & 30.33 & $0.0027^{* *}$ & 14 & 138.71 & $<0.0001^{* *}$ \\
\hline $\mathrm{N}$ & 7 & 47.17 & $<0.0001^{* *}$ & 2 & 390.75 & $<0.0001 * *$ & 14 & 25.89 & $<0.0001^{* *}$ \\
\hline $\mathrm{C}$ & 7 & 2557.41 & $<0.0001^{* *}$ & 2 & 7974.41 & $<0.0001 * *$ & 14 & 2023.37 & $<0.0001^{* *}$ \\
\hline S & 7 & 10.49 & $<0.0001^{* *}$ & 2 & 23.28 & $<0.0001 * *$ & 14 & 9.33 & $<0.0001^{* *}$ \\
\hline $\mathrm{P}$ & 7 & 57.80 & $<0.0001^{* *}$ & 2 & 422.49 & $<0.0001 * *$ & 14 & 83.49 & $<0.0001^{* *}$ \\
\hline $\mathrm{Cu}$ & 7 & 0.004 & 0.997 & 2 & 0.02 & 0.129 & 14 & 0.08 & 0.370 \\
\hline Mn & 7 & 0.07 & 0.0495 * & 2 & 0.55 & $<0.0001 * *$ & 14 & 0.05 & 0.691 \\
\hline $\mathrm{Zn}$ & 7 & 0.63 & $<0.0001^{* *}$ & 2 & 0.05 & 0.0475 * & 14 & 0.94 & $<0.0001 * *$ \\
\hline
\end{tabular}


Drought during the vegetative stage in $B$. juncea induces a decrease in the amount of almost all micronutrients such as $\mathrm{Zn}, \mathrm{Fe}, \mathrm{Mn}$, and $\mathrm{Cu}$ (Table 3). The observed decrease in the accumulation of microelements in terms of both stress factors might indicate the inhibition of the transport of these ions to the leaves of mustard. In stress conditions, a decrease in $\mathrm{Mn}, \mathrm{Fe}, \mathrm{Cu}$, and $\mathrm{Zn}$ levels may suggest a reduction in the synthesis of enzymes, especially of superoxide dismutase, which possesses these ions [82]. However, the magnitude of these micronutrients was slightly improved with further treatment of organic fertilizers under severe water stress (Table 3). There was also a significant interaction between fertilizer types and soil moisture levels for Fe in the leaves. Maximum amount of Fe $(7.19 \mathrm{mg} / \mathrm{mL})$ in $B$. juncea leaves was recorded in HO-treated plants under well-watered conditions.

Plants differ widely in nutrient accumulation and demand across developmental stages and species-specific survival strategies in response to biotic and abiotic factors imposed [83,84]. Here, specifically, we further focus to unravel the effect of severe water stress on macronutrient concentrations of $B$. juncea leaves within vegetative stage across different time and fertilizers treatment. Compared to the macronutrients content before the fertilizer application (0 DAT) there was a significant increase in $\mathrm{K}, \mathrm{Ca}, \mathrm{P}, \mathrm{Na}$, and $\mathrm{Mg}$ across time (Figures 1 and 2) under severe drought stress. While Na content followed the opposite pattern of $\mathrm{K}$ content (Figure 2), other micronutrients such as $\mathrm{Fe}, \mathrm{Mn}, \mathrm{Cu}$, and $\mathrm{Zn}$ revealed a non-significant increase in magnitude (data not shown). These dynamics in content of macronutrients within mustard leaves could be ascribed to difference in nutrient mobility and the physiological demand during vegetative growth. Most of these nutrients are relatively immobile in plant tissues which may affect their transport than accumulation, particularly calcium, iron, and zinc [85]. Contrasting with reproductive stage, the concentrations of the mobile nutrients such as $\mathrm{P}$ and $\mathrm{K}$ increased in during shoot elongation at early growth stage [83]. Further, nitrogen regulates the development of plant organs and exerts stronger control on vegetative growth than reproductive growth [86]. The K content was significantly increased at early vegetative growth stage than late vegetative growth stages under severe drought stress while fertilizers were applied. Similarly, Fernandez-Escobar et al. [87] have also shown that $\mathrm{K}$ concentration was higher at early vegetative growth stage than late vegetative growth stages. The poorly mobile nutrient $\mathrm{Ca}$ accumulated gradually in the leaves across time.

\subsection{Relationships between Traits}

Overall, total chlorophyll content (SPAD) was positively associated with RWC $(r=0.841)$, height $(r=0.79)$, LA $(r=0.826)$, MSI $(r=0.703)$, shoot biomass $(r=0.855)$, $\mathrm{Mg}(\mathrm{r}=0.828), \mathrm{Ca}(\mathrm{r}=0.816), \mathrm{N}(\mathrm{r}=0.908), \mathrm{C}(\mathrm{r}=0.76), \mathrm{P}(\mathrm{r}=0.81)$, and $\mathrm{Mn}(\mathrm{r}=0.774)$ significantly during the vegetative stage of mustard $(p \leq 0.001$, Table 6$)$. The strong association of SPAD with morphological traits (e.g., height and LA) might be linked to directly or indirectly to the effect of chlorophyll content on photosynthesis which could also ultimately impact shoot biomass and carbon content [88]. The positive association between SPAD and Mg mirror with its central location in chlorophyll structure and its integral role in modulating several physiological and biochemical processes containing the activation of plant growth enzymes $[89,90]$. Leaf area was positively correlated with leaf $\mathrm{N}$ concentrations $(\mathrm{r}=0.81)$ in our dataset. There were negative correlations between leaf $\mathrm{K}$ and $\mathrm{Ca}(\mathrm{r}=-0.01), \mathrm{K}$ and $\mathrm{Na}(\mathrm{r}=-0.049)$, and $\mathrm{K}$ and $\mathrm{Mg}(\mathrm{r}=-0.384)$ contents. The reduction in leaf $\mathrm{K}$ contents as a function of the increase in $\mathrm{Mg}$ and $\mathrm{Na}$ content might be due to the antagonistic effect among these nutrients for competing for the same site of the carriers in the membrane [91,92]. However, these correlations between leaf nutrient contents may not necessarily be maintained as these rely on soil moisture availability and nutrient uptake [19]. In sum, these findings imply that drought and fertilizer application may also modify cross talk between nutrients contents and hence modify the composition in the leaf. Micronutrients such as $\mathrm{Cu}, \mathrm{Mn}, \mathrm{Zn}$, and Fe were positively correlated with the majority of morpho-physiological traits and macronutrients except their negative association with RSR, Na (Mn and Zn), root biomass ( $\mathrm{Cu}$ and Fe), and K (Mn) (Table 6). 


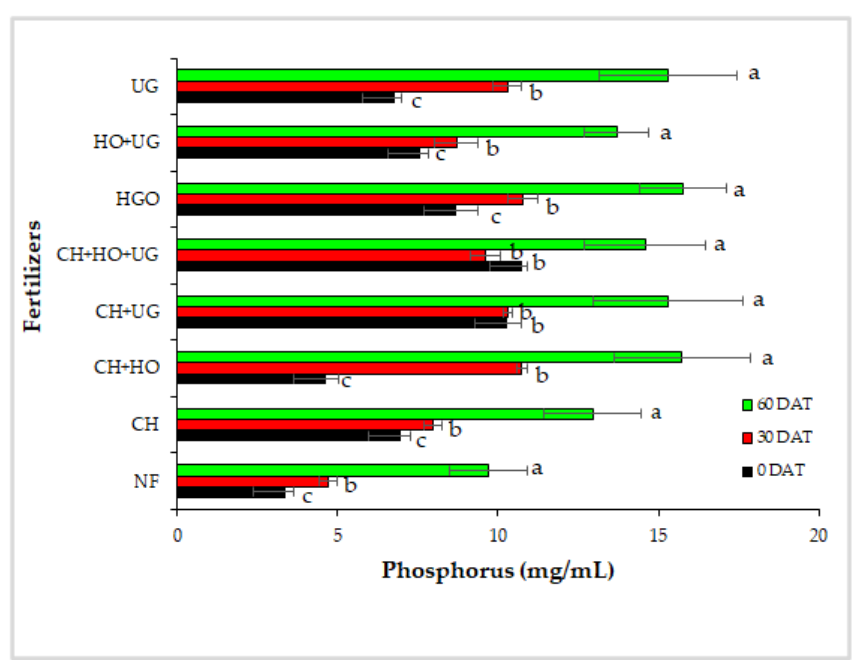

(a)

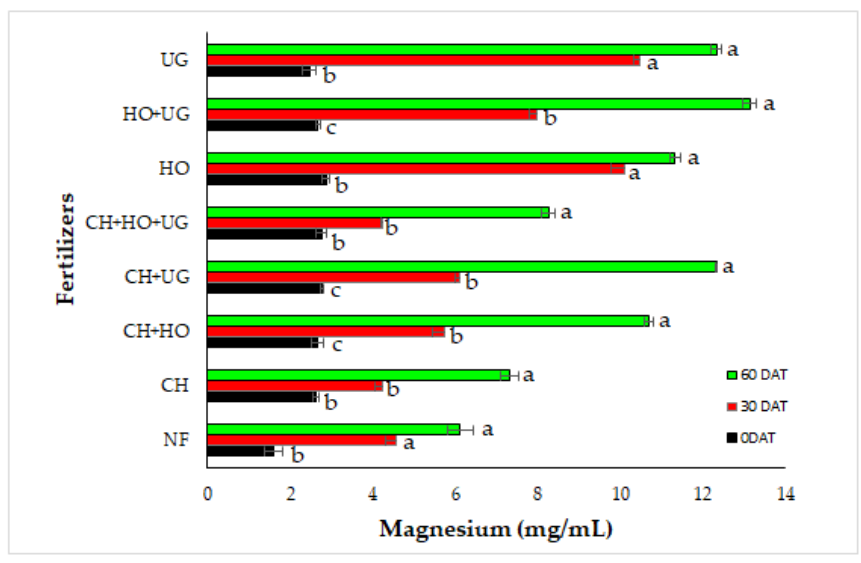

(b)

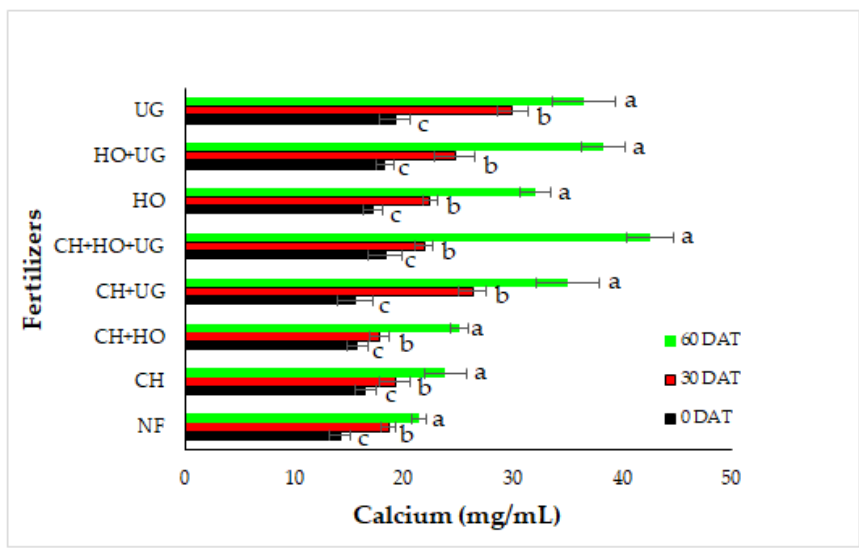

(c)

Figure 1. Short-term variation in $\mathrm{P}(\mathbf{a}), \mathrm{Mg}(\mathbf{b})$, and $\mathrm{Ca}(\mathbf{c})$ content of mustard plants treated with different organic fertilizers under severe water stress condition. Values are mean standard error. Different letters denote significant difference $(p \leq 0.05)$ among days after treatment when treated with a particular fertilizer or combined ones. $\mathrm{CH}=$ chitosan, $\mathrm{UG}=$ ultra-green, and $\mathrm{HO}=$ home-grown organic nutrition. 


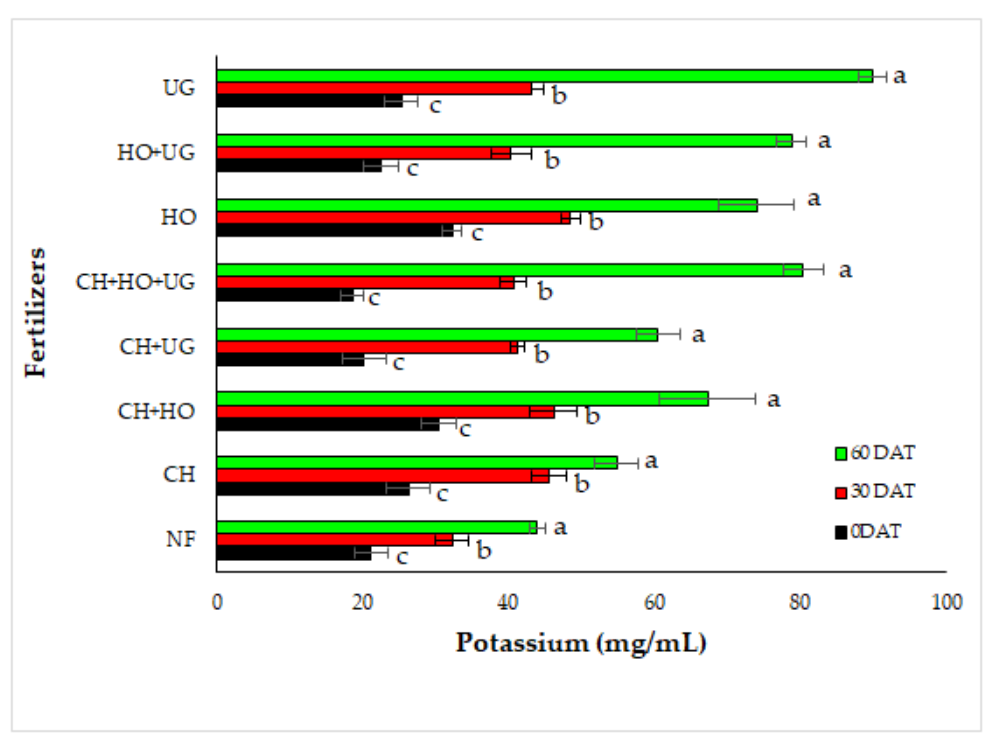

(a)

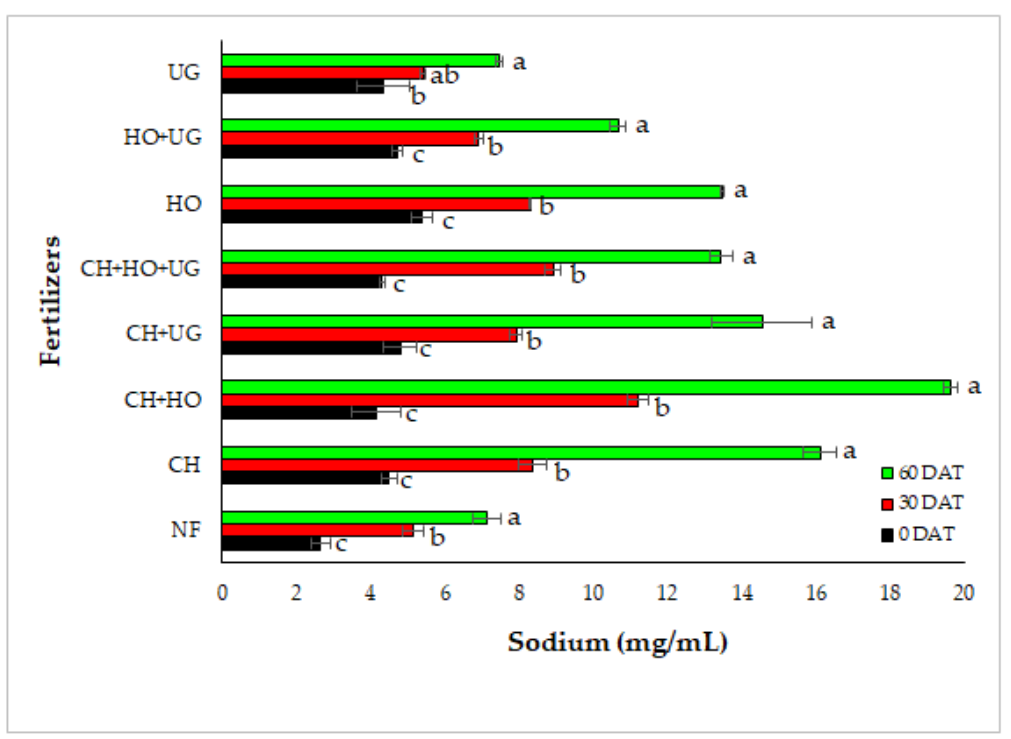

(b)

Figure 2. Short-term variation in $\mathrm{K}(\mathbf{a})$ and $\mathrm{Na}(\mathbf{b})$ content of mustard plants treated with different organic fertilizers under severe water stress condition. Values are mean standard error. Different letters denote significant difference $(p<0.05)$ among days after treatment when treated with a particular fertilizer or combined ones. $\mathrm{CH}=$ chitosan, $\mathrm{UG}=$ ultra-green, and $\mathrm{HO}=$ home-grown organic nutrition. 


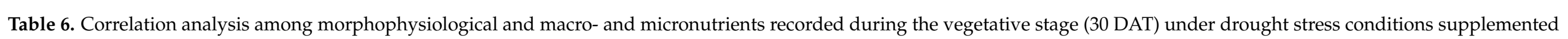
with organic fertilizers.

\begin{tabular}{|c|c|c|c|c|c|c|c|c|c|c|c|c|c|c|c|c|c|c|c|c|}
\hline & SPAD & RWC & Height & LA & SBM & RBM & RSR & $\mathbf{K}$ & $\mathrm{Mg}$ & $\mathrm{Na}$ & $\mathrm{Ca}$ & $\mathrm{Fe}$ & $\mathbf{N}$ & C & $S$ & MSI & $\mathbf{P}$ & $\mathrm{Cu}$ & Mn & $\mathrm{Zn}$ \\
\hline SPAD & & $* *$ & ** & $* *$ & ** & $* *$ & ** & ns & ** & ns & $* *$ & $* *$ & $* *$ & $* *$ & $* *$ & ** & ** & ns & ** & * \\
\hline RWC & 0.84 & & $* *$ & $* *$ & $* *$ & ns & $* *$ & ns & $* *$ & ns & $* *$ & $* *$ & $* *$ & $* *$ & ** & $* *$ & ** & * & $* *$ & $* *$ \\
\hline Height & 0.79 & 0.72 & & $* *$ & $* *$ & * & * & ns & $* *$ & ns & $* *$ & ns & $* *$ & $* *$ & $* *$ & $* *$ & $* *$ & ns & $* *$ & * \\
\hline SBM & 0.85 & 0.82 & 0.76 & 0.78 & & $* *$ & $* *$ & ns & $* *$ & ns & $* *$ & ns & $* *$ & $* *$ & $* *$ & $* *$ & $* *$ & * & $* *$ & * \\
\hline RBM & 0.30 & 0.16 & 0.24 & 0.125 & 0.32 & & $* *$ & ns & ns & ns & * & ns & ns & * & ns & ns & * & ns & $*$ & ns \\
\hline RSR & -0.34 & -0.46 & -0.29 & -0.50 & -0.45 & 0.61 & & ns & $*$ & ns & $* *$ & ns & $* *$ & $* *$ & $* *$ & $* *$ & $* *$ & $*$ & * & $\mathrm{ns}$ \\
\hline K & 0.08 & 0.141 & 0.19 & 0.03 & 0.04 & 0.01 & 0.01 & & $* *$ & ns & $\mathrm{ns}$ & ns & ns & ns & * & * & ns & ns & ns & $\mathrm{ns}$ \\
\hline $\mathrm{Na}$ & -0.16 & -0.06 & 0.18 & -0.13 & -0.08 & -0.17 & -0.04 & -0.05 & -0.03 & & $* *$ & ns & ns & ns & $\mathrm{ns}$ & $* *$ & ns & ns & $* *$ & $\mathrm{~ns}$ \\
\hline $\mathrm{Ca}$ & 0.83 & 0.68 & 0.75 & 0.85 & 0.78 & 0.28 & -0.32 & -0.01 & 0.74 & -0.01 & & $*$ & $* *$ & $* *$ & $* *$ & $* *$ & $* *$ & ns & $* *$ & ns \\
\hline $\mathrm{Fe}$ & 0.32 & 0.38 & 0.22 & 0.29 & 0.21 & -0.06 & -0.09 & -0.18 & 0.17 & 0.03 & 0.25 & & $* *$ & ns & $* *$ & $* *$ & $* *$ & ns & $* *$ & * \\
\hline $\mathrm{N}$ & 0.91 & 0.88 & 0.70 & 0.81 & 0.80 & 0.17 & -0.43 & 0.01 & 0.75 & -0.16 & 0.73 & 0.33 & & $* *$ & $* *$ & $* *$ & $* *$ & ns & $* *$ & * \\
\hline C & 0.76 & 0.76 & 0.70 & 0.52 & 0.78 & 0.25 & -0.35 & 0.05 & 0.70 & -0.09 & 0.55 & 0.22 & 0.80 & & $* *$ & $* *$ & $* *$ & ns & $* *$ & * \\
\hline$S$ & 0.66 & 0.73 & 0.59 & 0.57 & 0.65 & 0.07 & -0.35 & 0.24 & 0.68 & 0.03 & 0.54 & 0.13 & 0.68 & 0.67 & & $* *$ & $* *$ & ns & $* *$ & ns \\
\hline MSI & 0.70 & 0.60 & 0.38 & 0.71 & 0.58 & 0.09 & -0.37 & -0.28 & 0.36 & -0.32 & 0.58 & 0.33 & 0.77 & 0.59 & 0.53 & & $* *$ & ns & $* *$ & $\mathrm{~ns}$ \\
\hline $\mathrm{P}$ & 0.81 & 0.81 & 0.74 & 0.80 & 0.79 & 0.24 & -0.40 & 0.08 & 0.61 & -0.17 & 0.64 & 0.33 & 0.79 & 0.71 & 0.57 & 0.64 & & $*$ & $* *$ & $* *$ \\
\hline $\mathrm{Cu}$ & 0.18 & 0.24 & 0.19 & 0.24 & 0.24 & -0.06 & -0.25 & 0.05 & 0.18 & 0.06 & 0.18 & 0.04 & 0.16 & 0.11 & 0.22 & 0.09 & 0.25 & & ns & ns \\
\hline $\mathrm{Zn}$ & 0.28 & 0.34 & 0.28 & 0.23 & 0.26 & 0.07 & -0.11 & 0.04 & 0.14 & -0.09 & 0.04 & 0.29 & 0.26 & 0.30 & 0.06 & 0.14 & 0.49 & 0.09 & 0.14 & \\
\hline
\end{tabular}

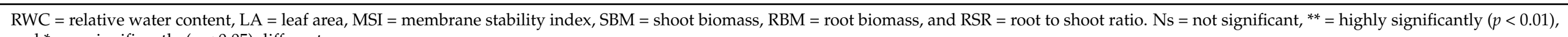
and $^{*}=$ as significantly $(p<0.05)$ different. 


\section{Conclusions}

In summary, this study highlights the deleterious effect of drought on growth and physiological traits and leaf nutrient content of $B$. juncea at vegetative stage. However, we found that application of combined organic fertilizers mitigates the adverse effects of drought on the mustard plants synergistically by increasing plant height, leaf area, relative water content, chlorophyll content, membrane stability, and shoot biomass, but not root biomass. Moreover, the present study showed a significant effect of soil moisture level, fertilizer type, and their interaction on content of macronutrients $(\mathrm{Ca}, \mathrm{K}, \mathrm{P}, \mathrm{N}, \mathrm{C}, \mathrm{S}, \mathrm{Na}$, $\mathrm{Mg})$ and micronutrients $(\mathrm{Fe}, \mathrm{Zn})$ in mustard leaves. Specifically, under severe drought stress, application of different organic fertilizers significantly and complexly affects the short-term temporal dynamic of macronutrients such as K, N, P, Ca, and Mg. The trends in our results seem to indicate that organic fertilizers might be most helpful in drought-prone environments with limited inorganic fertilizer input. Finally, we suggest the importance of studying the mechanism(s) by which the application of organic fertilizers affect plant organ-specific nutrient dynamics/homeostasis and secondary metabolites production in responses to drought stress by transcriptomic approaches. Such approaches can provide a full picture of intricate interaction of drought and organic fertilizers on growth and nutrient dynamics in the leaves of $B$. juncea improvement potentially that could provide health benefits for consumers. Furthermore, it would be interesting to continue the study of the combined influence of drought and organic fertilizers for several years, to compare annual results between them, in order to find out if drought effect mitigation by organic fertilizer application is sustainable.

Supplementary Materials: The following are available online at https: / www.mdpi.com/article/ 10.3390/su132413948/s1, Table S1: Generalized regression model showing parameter estimates of relative treatment effects on response variables.

Author Contributions: A.G. developed the concept including the method, data curation, formal statistical analysis, and writing - original draft. L.C. contributed to resources, funding acquisition, project administration, and reviewing. S.W. conducted nutrient analysis and writing - review and editing. C.C. and E.P. contributed to the morpho-physiological measurements and laboratory nutrient analysis, respectively. A.W. evaluated treatment combinations and contributed to writing-review and editing the draft of the manuscript. All authors have read and agreed to the published version of the manuscript.

Funding: This work was partially funded by the United States Department of Agriculture National Institute of Food and Agriculture (USDA-NIFA) Evans-Allen Grant 180835-82601 and USDA NIFA Capacity Building Project \# 2019-38821-29036.

Data Availability Statement: The data presented in this study are available on request from the corresponding author.

Conflicts of Interest: The authors declare that they have no conflict of interest.

\section{References}

1. Sharma, A.; Kumar, V.; Kanwar, M.K.; Thukral, A.K.; Bhardwajm, R. Phytochemical profiling of the leaves of Brassica juncea L. using GC-MS. J. Int. Food Res. 2017, 24, 547-551.

2. Sharma, A.; Rai, P.K.; Prasad, S. GC-MS detection and determination of major volatile compounds in Brassica juncea L. leaves and seeds. J. Microchem. 2018, 138, 488-493. [CrossRef]

3. Majdoub, Y.Q.; Alibrando, F.; Cacciola, F.; Arena, K.; Pagnotta, E.; Matteo, R.; Micalizzi, G.; Dugo, L.; Dugo, P.; Mondello, L. Chemical Characterization of Three Accessions of Brassica juncea L. Extracts from Deferent Plant Tissues. Molecules 2020, $25,5421$. [CrossRef] [PubMed]

4. Chauhan, J.S.; Tyagi, M.K.; Kumar, A.; Nashaat, N.I.; Singh, M.; Singh, N.B.; Welham, S.J. Drought effects on yield and its components in Indian mustard (Brassica juncea L.). Plant Breed. 2007, 126, 399-402. [CrossRef]

5. Mahrookashani, A.; Siebert, S.; Heuging, H.; Ewert, F. Independent and combined effects of high temperature and drought stress around anthesis on wheat. J. Agron. Crop Sci. 2017, 203, 453-463. [CrossRef] 
6. Bandeppa, S.; Paul, S.; Kumar, J.; Chandrashekar, T.N.; Umesh, D.K.; Aggarwal, C.; Asha, A.D. Antioxidant, physiological and biochemical responses of drought susceptible and drought tolerant mustard (Brassica juncea L.) genotypes to rhizobacterial inoculation under water deficit stress. Plant Physiol. Biochem. 2019, 143, 19-28. [CrossRef]

7. Chauhan, J.S.; Singh, K.H.; Singh, V.V.; Kumar, S. Hundred years of rapeseed mustard breeding in India: Accomplishments and future strategies. Indian J. Agric. Sci. 2011, 81, 1093-1109.

8. Mirzaei, A.; Naseri, R.; Moghadam, A.; Esmailpour-Jahromi, M. The effects of drought stress on seed yield and some agronomic traits of canola cultivars at different growth stages. Bull. Environ. Pharmacol. Life Sci. 2013, 2, 115-121.

9. Kapoor, D.; Bhardwaj, S.; Landi, M.; Sharma, A.; Ramakrishnan, M.; Sharma, A. The Impact of Drought in plant metabolism: How to exploit tolerance mechanisms to increase crop production. Appl. Sci. 2020, 10, 5692. [CrossRef]

10. Matiu, M.; Ankerst, D.P.; Menzel, A. Interactions between temperature and drought in global and regional crop yield variability during 1961-2014. PLOS ONE 2017, 12, e0178339.

11. Bistgani, Z.E.; Siadat, S.A.; Bakhshandeh, A.; Pirbalouti, A.G.; Hashemi, M. Interactive effects of drought stress and chitosan application on physiological characteristics and essential oil yield of Thymus daenensis Celak. Crop J. 2017, 5, 407-415. [CrossRef]

12. Pandey, P.; Irulappan, V.; Bagavathiannan, M.V.; Senthil-Kumar, M. Impact of combined abiotic and biotic stresses on plant growth and avenues for crop improvement by exploiting physio-morphological traits. Front. Plant Sci. 2017, 8, 537. [CrossRef]

13. Fahad, S.; Bajwa, A.A.; Nazir, U.; Anjum, S.A.; Farooq, A.; Zohaib, A.; Sadia, S.; Nasim, W.; Adkins, S.; Saud, S.; et al. Crop production under drought and heat stress: Plant responses and management options. Front. Plant Sci. 2017, 8, 1147. [CrossRef]

14. Wang, P.; Su, L.; Gao, H.; Jiang, X.; Wu, X.; Wang, Y.; Ren, F. Genome-wide characterization of bHLH genes in grape and analysis of their potential relevance to abiotic stress tolerance and secondary metabolite biosynthesis. Front Plant Sci. 2018, 9, 64. [CrossRef] [PubMed]

15. Hussain, F.; Hussain, I.; Khan, A.H.A.; Muhammad, Y.S.; Iqbal, M.; Soja, G.; Reichenauer, T.G.; Zeshan; Yousaf, S. Combined application of biochar, compost, and bacterial consortia with Italian ryegrass enhanced phytoremediation of petroleum hydrocarbon contaminated soil. Environ. Exp. Bot. 2018, 153, 80-88. [CrossRef]

16. Tadayyon, A.; Nikneshan, P.; Pessarakli, M. Effects of drought stress on concentration of macro and micronutrients in castor (Ricinus communis L.) plant. J. Plant Nutr. 2018, 41, 304-310. [CrossRef]

17. Hu, Y.; Schmidhalter, U. Drought and salinity: A comparison of their effects on mineral nutrition of plants. J. Plant Nutr. Soil Sci. 2005, 168, 541-549. [CrossRef]

18. Bista, D.R.; Heckathorn, S.A.; Jayawardena, D.M.; Mishra, S.; Boldt, J.K. Effects of drought on nutrient uptake and the levels of nutrient-uptake proteins in roots of drought-sensitive and -tolerant grasses. Plants 2018, 7, 28. [CrossRef]

19. Ghandilyan, A.; Barboza, L.; Tisné, S.; Granier, C.; Reymond, M.; Koornneef, M.; Schat, H.; Aarts, M.G.M. Genetic analysis identifies quantitative trait loci controlling rosette mineral concentrations in Arabidopsis thaliana under drought. N. Phytol. 2009, 184, 180-192. [CrossRef]

20. Masclaux-Daubresse, C.; Daniel-Vedele, F.; Dechorgnat, J.; Chardon, F.; Gaufichon, L.; Suzuki, A. Nitrogen uptake, assimilation and remobilization in plants: Challenges for sustainable and productive agriculture. Ann. Bot. 2010, 105, 1141-1157. [CrossRef] [PubMed]

21. Etienne, P.; Diquelou, S.; Prudent, M.; Salon, C.; Maillard, A.; Ourry, A. Macro and micronutrient storage in plants and their remobilization when facing scarcity: The case of drought. Agriculture 2018, 8, 14. [CrossRef]

22. Alsafar, M.S.; Al-Hassan, Y.M. Effect of nitrogen and phosphorus fertilizers on growth and oil yield of indigenous Mint (Mentha longifolia L.). Biotechnology 2009, 8, 380-384. [CrossRef]

23. Dong, W.; Qin, J.; Li, J.; Zhao, Y.; Nie, L.; Zhang, Z. Interactions between soil water content and fertilizer on growth characteristics and biomass yield of Chinese white poplar (Populus tomentosa Carr) seedlings. Soil Sci. Plant Nutr. 2011, 57, 303-312. [CrossRef]

24. Bindraban, P.S.; Dimkpa, C.O.; Pandey, R. Exploring phosphorus fertilizers and fertilization strategies for improved human and environmental health. Biol. Fertil. Soils 2020, 56, 299-317. [CrossRef]

25. Rezaei, R.; Valadabadi, S.A.; Rad, S.A.H.; Sayfzadeh, S.; Masouleh, H.E. The effects of application of biological fertilizers and different amounts of urea fertilizer sources under low water stress conditions on physiological traits of medicinal plant (Calendula officinalis L.). Appl. Ecol. Environ. Res. 2018, 16, 4813-4827. [CrossRef]

26. Azab, E. Effect of water stress and biological fertilization on maize growth, chemical composition and productivity in calcareous. Am. J. Plant Physiol. 2016, 11, 1-11. [CrossRef]

27. Ghosh, M.; Devi, A. Assessment of crop growth, soil properties and crop yield in an upland acidic soil with inorganic fertilizer blended with organic amendments in summer rice cropping seasons. Int. J. Recycl. Org. Waste Agricult. 2019, 8, 3647. [CrossRef]

28. Guan, Y.; Jin Hu, J.; Wang, X.; Shao, C. Seed priming with chitosan improves maize germination and seedling growth in relation to physiological changes under low temperature stress. J. Zhejiang Univ. Sci. 2009, 10, 427-433. [CrossRef]

29. Pokorska-Niewiada, K.; Rajkowska-Mysliwiec, M.; Protasowicki, M. Acute lethal toxicity of heavy metals to the seeds of plants of high importance to humans. Bull. Environ. Contam. Toxicol. 2018, 101, 222-228. [CrossRef]

30. Kebrom, T.H.; Douglas, R.; Bandara, S.; Woldesenbet, S.; Carson, L.; Kidane, N. Identification of phytotoxic levels of copper and nickel in commercial organic soil amendments recycled from poultry farms and municipal wastes. Bull. Environ. Contam. Toxicol. 2020, 105, 921-926. [CrossRef]

31. Bardhan, K.; York, L.M.; Hasanuzzaman, M.; Parekh, V.; Jena, S.; Pandya, M.N. Can smart nutrient applications optimize the plant's hidden half to improve drought resistance? Physiol. Plant. 2021, 172, 1007-1015. [CrossRef] 
32. Fan, Y.; Massey, R.; Park, S.C. Multi-crop production decisions and economic irrigation water use efficiency: The effects of water costs, pressure irrigation adoption, and climatic determinants. Water 2018, 10, 1637. [CrossRef]

33. Neugart, S.; Baldermann, S.; Hanschen, F.S.; Klopsch, R.; Wiesner-Reinhold, M.; Schreiner, M. The intrinsic quality of brassicaceous vegetables: How secondary plant metabolites are affected by genetic, environmental, and agronomic factors. Sci. Hortic. 2018, 233, 460-478. [CrossRef]

34. González-Chavira, M.M.; Herrera-Hernández, M.G.; Guzmán-Maldonado, H.; Pons-Hernández, J.L. Controlled water deficit as abiotic stress factor for enhancing the phytochemical content and adding-value of crops. Sci. Hortic. 2018, 234, 354-360. [CrossRef]

35. Vimala, P.; Roff, M.N.; Shokri, A.O.; Lim, A.H. Effect of organic fertilizer on the yield and nutrient content of leaf-mustard (Brassica juncea) organically grown under shelter. J. Trop. Agric. Food Sci. 2010, 38, 153-160.

36. Reganold, J.P.; Wachter, J.M. Organic agriculture in the twenty-first century. Nat. Plants 2016, 2, 15221. [CrossRef]

37. Wortman, S.E.; Holmes, A.A.; Miernicki, E.; Knoche, K.; Pittelkow, C.M. First-season crop yield response to organic soil amendments: A meta- analysis. J. Agron. 2017, 109, 1210-1217. [CrossRef]

38. Bouyoucos, C. Les Proprie éte és Physiques du sol de éPendent de sa Texture Etde sa Structure, Les Bases de la Production Vegetale, Tome 1; Collectionsciences et Techniques Agricoles: Bressuire, France, 1983; pp. 67-87.

39. Ramil, N.H.; Sulaiman, Z.A. Effects of different fertilizers formulas on the growth and development of leaf mustard. Brassica Juncea J. Acad. 2021, 9, 145-152.

40. Barrs, H.D.; Weatherley, P.E. A re-examination of the relative turgidity technique for estimating water deficits in leaves. Aust. J. Biol. Sci. 1962, 15, 413-428. [CrossRef]

41. Sairam, R.K. Effect of moisture stress on physiological activities of two contrasting wheat genotypes. Indian J. Exp. Biol. 1994, 32, 584-593.

42. R Core Team. R: A Language and Environment for Statistical Computing; R Foundation for Statistical Computing: Vienna, Austria, 2013; Available online: http:/ / www.R-project.org/ (accessed on 29 August 2021).

43. Mendiburu, F. Agricolae: Statistical Procedures for Agricultural Research. R Package Version 1.1-4. 2013. Available online: https:/ / CRAN.R-project.org/package=agricolae (accessed on 5 June 2021).

44. Hosseini, S.M.; Hassibi, P. Effects of water deficit stress on several quantitative and qualitative characteristics of canola (Brassica napus L.) cultivars. Not. Sci. Biol. 2011, 3, 120-125. [CrossRef]

45. Mbatha, T.P.; Modi, A.T. Response of local mustard germplasm to water stress. S. Afr. J. Plant Soil 2010, 27, 328-330. [CrossRef]

46. Maseko, I.; Ncube, B.; Tesfay, S.; Fessehazion, M.; Modi, A.T.; Mabhaudhi, T. Productivity of selected African leafy vegetables under varying water regimes. Agronomy 2020, 10, 916. [CrossRef]

47. Larkunthod, P.; Nounjan, N.; Siangliw, J.L.; Toojinda, T.; Sanitchon, J.; Jongdee, B.; Theerakulpisut, P. Physiological responses under drought stress of improved drought-tolerant rice lines and their parents. Not. Bot. Horti Agrobot. 2018, 46, 679-687. [CrossRef]

48. Bangar, P.; Chaudhury, A.; Tiwari, B.; Kumar, S.; Kumari, R.; Bhat, K.V. Morphophysiological and biochemical response of mungbean [Vigna radiata (L.) Wilczek] varieties at different developmental stages under drought stress. Turk. J. Biol. 2019, 43, 58-69. [CrossRef]

49. Kaya, M.D.; Okcub, G.; Ataka, M.; Cikilic, Y.; Kolsaricia, O. Seed treatments to overcome salt and drought stress during germination in sunflower (Helianthus annus L.). Eur. J. Agron. 2006, 24, 291-295. [CrossRef]

50. Guo, X.; Li, S.; Wang, D.; Huang, Z.; Sarwar, N.; Mubeen, K.; Shakeel, M.; Hussain, M. Effects of water and fertilizer coupling on the physiological characteristics and growth of rabbiteye blueberry. PLoS ONE 2021, 16, e0254013. [CrossRef]

51. Husen, A.; Iqbal, M.; Aref, I.M. Growth, water status, and leaf characteristics of Brassica carinata under drought and rehydration conditions. Braz. J. Bot. 2014, 37, 217-227. [CrossRef]

52. Brunetti, G.; Traversa, A.; De Mastro, F.; Cocozza, C. Short term effects of synergistic inorganic and organic fertilization on soil properties and yield and quality of plum tomato. Sci. Hortic. 2019, 252, 342-347. [CrossRef]

53. Li, Z.; Zhang, Y.; Zhang, X.; Merewitz, E.; Peng, Y.; Ma, X.; Yan, Y. Metabolic pathways regulated by chitosan contributing to drought resistance in white clover. J. Proteome Res. 2017, 16, 3039-3052. [CrossRef]

54. Dimkpa, C.O.; Fugice, J.; Singh, U.; Lewis, T.D. Development of fertilizers for enhanced nitrogen use efficiency-Trends and perspectives. Sci. Total Environ. 2020, 731, 139113. [CrossRef] [PubMed]

55. Moreno-Jiménez, E.; Plaza, C.; Saiz, H.; Manzano, R.; Flagmeier, M.; Maestre, F.T. Aridity and reduced soil micronutrient availability in global drylands. Nat. Sustain. 2019, 2, 371-377. [CrossRef] [PubMed]

56. Farouk, S.; Amany, A.R. Improving growth and yield of cowpea by foliar application of chitosan under water stress. Egypt J. Biol. 2012, 14, 14-16. [CrossRef]

57. Pirbalouti, A.G.; Malekpoor, F.; Salimi, A.; Golparvar, A. Exogenous application of chitosan on biochemical and physiological characteristics, phenolic content and antioxidant activity of two species of basil (Ocimum ciliatum and Ocimum basilicum) under reduced irrigation. Sci. Hortic. 2017, 217, 114-122. [CrossRef]

58. Ghassemi-Golezani, K.; Afkhami, N. Changes in some morpho-physiological traits of safflower in response to water deficit and nano-fertilizers. J. Bus. Econ. Stat. 2018, 12, 391-398.

59. Deka, D.; Singh, A.K.; Singh, A.K. Effect of Drought Stress on Crop Plants with Special Reference to Drought Avoidance and Tolerance Mechanisms: A Review. Int. J. Curr. Microbiol. Appl. Sci. 2018, 7, 2703-2721. [CrossRef] 
60. Haworth, M.; Marino, G.; Brunetti, C.; Killi, D.; Carlo, A.; Centritto, M. The impact of heat stress and water deficit on the photosynthetic and stomatal physiology of olive (Olea europaea L.)-A case study of the 2017 heatwave. Plants 2018, 7, 76. [CrossRef] [PubMed]

61. Beykkhormizi, A.; Abrishamchi, P.; Ganjeali, A.; Parsa, M. Effect of vermicompost on some morphological, physiological and biochemical traits of bean (Phaseolus vulgaris L.) under salinity stress. J. Plant Nutr. 2016, 39, 883-893. [CrossRef]

62. Ratnasekera, D.P.; Subhashi, A.P.T. Morpho-physiological response of selected Sri Lankan mungbean (Vigna radiata L.) genotypes to drought stress. J. AgriSearch. 2015, 2, 62-66.

63. Ahmadizadeh, M.; Nori, A.; Shahbazi, H.; Habibpour, M. Effects of drought stress on some agronomic and morphological traits of durum wheat (Triticum durum Desf.) landraces under greenhouse condition. Afr. J. Biotechnol. 2011, 10, 14097-14107.

64. Hosseinzadeh, S.R.; Amiri, H.; Ismaili, A. Evaluation of photosynthesis, physiological, and biochemical responses of chickpea (Cicer arietinum L. cv. Pirouz) under water deficit stress and use of vermicompost fertilizer. J. Integr. Agric. 2018, 17, $2426-2437$. [CrossRef]

65. Gurumurthy, S.; Sarkar, B.; Vanaja, M.; Lakshmi, J.; Yadav, S.; Maheswari, M. Morpho-physiological and biochemical changes in black gram (Vigna mungo L. Hepper) genotypes under drought stress at flowering stage. Acta Physiol. Plant 2019, 41, 42. [CrossRef]

66. Malerba, M.; Cerana, R. Chitosan Effects on Plant Systems. Int. J. Mol. Sci. 2016, 17, 996. [CrossRef] [PubMed]

67. Chowdhury, J.; Karim, M.; Khaliq, Q.; Ahmed, A. Effect of drought stress on bio-chemical change and cell membrane stability of soybean genotypes. Bangladesh J. Agric. Res. 2017, 42, 475-485. [CrossRef]

68. Majidi, M.M.; Rashidi, F.; Sharafi, Y. Physiological traits related to drought tolerance in Brassica. Int. J. Parallel Progr. 2015, 9, 541-560.

69. Kazeminasab, A.; Yarnia, M.; Lebaschy, M.H.; Mirshekari, B.; Rejali, F. The effect of vermicompost and PGPR on physiological traits of lemon balm (Melissa officinalis L.) plant under drought stress. JMPB 2016, 2, 135-144.

70. Tekaya, M.; El-Gharbi, S.; Mechri, B.; Chehab, H.; Bchir, A.; Chraief, I.; Ayachi, M.; Boujnah, D.; Attia, F.; Hammami, M. Improving performance of olive trees by the enhancement of key physiological parameters of olive leaves in response to foliar fertilization. Acta Physiol. Plant. 2016, 38, 101-109. [CrossRef]

71. Akram, M.S.; Ashraf, M. Alleviation of adverse effects of salt stress on sunflower (Helianthus annuus L.) by exogenous application of potassium nitrate. J. Appl. Bot. Food Qual. 2009, 83, 19-27.

72. Sanaullah, M.; Rumpel, C.; Charrier, X.; Chabbi, A. How does drought stress influence the decomposition of plant litter with contrasting quality in a grassland ecosystem? Plant Soil 2012, 352, 277-288. [CrossRef]

73. Lambers, H.; Chapin, F.S.; Pons, T.L. Ecosystem and Global Processes: Ecophysiological Controls. In Plant Physiological Ecology, 2nd ed.; Springer: New York, NY, USA, 2008; p. 559.

74. Egilla, J.N.; Davies, F.T.; Boutton, T.W. Drought stress influences leaf water content, photosynthesis, and water-use efficiency of hibiscus rosa-sinensis at three potassium concentrations. Photosynthetica 2005, 43, 135-140. [CrossRef]

75. Cakmak, I. The role of potassium in alleviating detrimental effects of abiotic stresses in plants. J. Plant Nutr. Soil Sci. 2005, 168, 521-530. [CrossRef]

76. Sucre, B.; Suarez, N. Effect of salinity and PEG-induced water stress on water status, gas exchange, solute accumulation, and leaf growth in Ipomoea Pescaprae. Environ. Exp. Bot. 2011, 70, 192-203. [CrossRef]

77. Shaul, O. Magnesium transport and function in plants: The tip of the iceberg. Biometals 2002, 15, 309-323. [CrossRef]

78. Chatelain, P.G.; Pintado, M.E.; Vasconcelos, M.W. Evaluation of chitooligosaccharide application on mineral accumulation and plant growth in Phaseolus vulgaris. Plant Sci. 2014, 215, 134-140. [CrossRef]

79. Yang, H.; Jie, Y. Uptake and Transport of Calcium in Plants. J. Plant Physiol. Mol. Biol. 2005, 31, $227-234$.

80. Waraich, E.A.; Ahmad, R.; Saifullah, M.Y.; Ashraf, E. Role of mineral nutrition in alleviation of drought stress in plants. Aust. J. Crop Sci. 2011, 5, 764-777.

81. Adhikary, S. Vermicompost, the story of organic gold: A review. Agric. Sci. 2012, 3, 905-917. [CrossRef]

82. Filek, M.; Walas, S.; Mrowiec, H.; Rudolphy-Skorska, E.; Sieprawska, A.; Biesaga-Koscielniak, J. Membrane permeability and micro- and macroelement accumulation in spring wheat cultivars during the short-term effect of salinity- and PEG-induced water stress. Acta Physiol. Plant 2012, 34, 985-995. [CrossRef]

83. Peng, H.; Chen, Y.; Yan, Z.; Han, W. Stage-dependent stoichiometric homeostasis and responses of nutrient resorption in Amaranthus mangostanus to nitrogen and phosphorus addition. Sci. Rep. 2016, 6, 37219. [CrossRef]

84. Chen, Y.E.; Yuan, S.; Liu, H.M.; Chen, Z.Y.; Zhang, Y.H.; Zhang, H.Y. A combination of chitosan and chemical fertilizers improves growth and disease resistance in Begonia hiemalis Fotsch. Hortic. Environ. Biotechnol. 2016, 57, 1-10. [CrossRef]

85. Maillard, A.; Etienne, P.; Diquélou, S.; Trouverie, J.; Billard, V.; Yvin, J.C.; Ourry, A. Nutrient deficiencies modify the ionomic composition of plant tissues: A focus on crosstalk between molybdenum and other nutrients in Brassica napus. J. Exp. Bot. 2016, 67, 5631-5641. [CrossRef] [PubMed]

86. Sosa, A.; Padilla, J.; Ortiz, J.; Etchevers, J.D. Biomass Accumulation and its Relationship with the Demand and Concentration of Nitrogen, Phosphorus, and Potassium in Lettuce. Commun. Soil Sci. Plant Anal. 2012, 43, 121-133. [CrossRef]

87. Fernández-Escobar, R.; Antonaya-Baena, M.F.; Sánchez-Zamora, M.A.; Molina-Soria, C. The amount of nitrogen applied and nutritional status of olive plants affect nitrogen uptake efficiency. Sci. Hortic. 2014, 167, 1-4. [CrossRef] 
88. Ahmad, A.; Selim, M.M.; Alderfasi, A.A.; Afzal, M. Effect of drought stress on mung bean (Vigna radiata L.) under arid climatic conditions of Saudi Arabia. In Ecosystem and Sustainable Development; Miralles Garcia, J.L., Brebbia, C.A., Eds.; WIT Press: Southampton, UK, 2015; pp. 185-193.

89. Hawkesford, M.; Horst, W.; Kichey, T.; Lambers, H.; Schjoerring, J.; Møller, I.S. Functions of macronutrients. In Marschner's Mineral Nutrition of Higher Plants, 3rd ed.; Academic Press: Waltham, MA, USA; Elsevier: Amsterdam, The Netherlands, 2012; pp. 135-189.

90. Cakmak, I.; Kirkby, E.A. Role of magnesium in carbon partitioning and alleviating photooxidative damage. Physiol. Plant. 2008, 133, 692-704. [CrossRef]

91. Ding, Y.; Xu, G. Low magnesium with high potassium supply changes sugar partitioning and root growth pattern prior to visible magnesium deficiency in leaves of Rice (Oryza sativa L.). Am. J. Plant Sci. 2011, 2, 601-608. [CrossRef]

92. Marschner, H. Mineral Nutrition of Higher Plants, 3rd ed.; Academic Press: London, UK, 2012; pp. 315-330. 